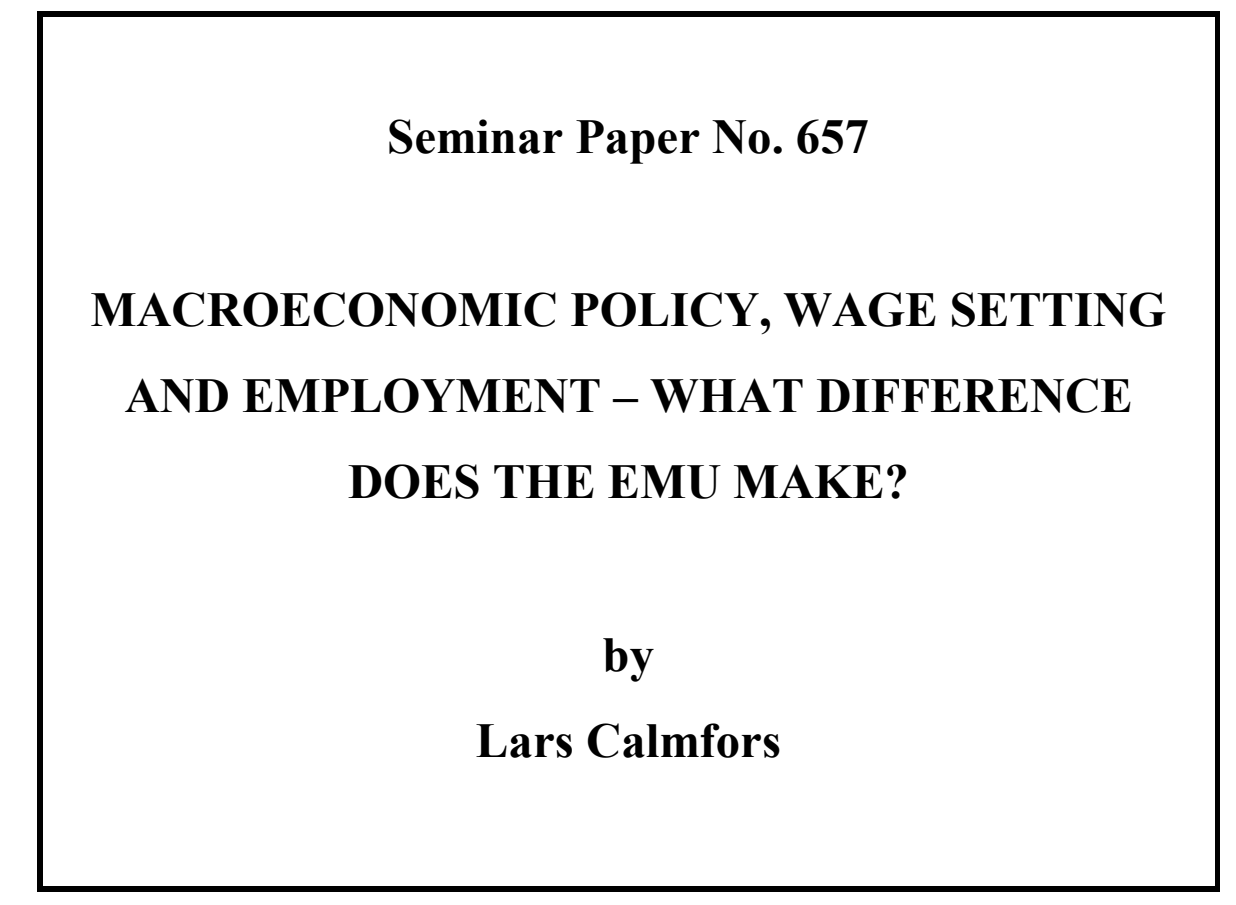

MACROECONOMIC POLICY, WAGE SETTING AND EMPLOYMENT - WHAT DIFFERENCE DOES THE EMU MAKE?

Lars Calmfors

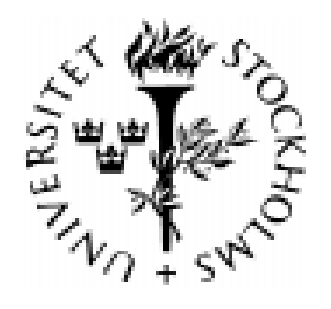

INSTITUTE FOR INTERNATIONAL ECONOMIC STUDIES Stockholm University 
ISSN 0347-8769

Seminar Paper No. 657

MACROECONOMIC POLICY, WAGE SETTING AND
EMPLOYMENT - WHAT DIFFERENCE DOES THE EMU MAKE?

by

Lars Calmfors

Papers in the seminar series are also published on internet in postscript and Adobe Acrobat (PDF) formats.

Download from http://www.iies.su.se/

Seminar Papers are preliminary material circulated to stimulate discussion and critical comment.

October 1998

Institute for International Economic Studies

S-106 91 Stockholm

Sweden 


\title{
Macroeconomic Policy, Wage Setting and Employment - What Difference Does the EMU Make?
}

\author{
by Lars Calmfors* \\ Institute for International Economic Studies, Stockholm University.
}

\begin{abstract}
The likely impact of the EMU on the variability and level of employment is analysed. The major conclusions are: (1) Although an inflation-target regime will constrain monetary policy of a non-participant in the EMU, it still leaves considerable scope for exchange-rate changes in the case of country-specific demand shocks, provided that there is some nominal price and wage flexibility. (2) Variations in payroll taxes can be used as a substitute for exchange-rate changes in the EMU, but it will be an imperfect substitute. (3) Money-wage flexibility is likely to be larger inside than outside the EMU, but probably not by much. (4) There are various mechanisms through which the EMU may affect the incentives for labour-market reform to reduce equilibrium unemployment, but the net impact is highly uncertain.
\end{abstract}

JEL classification: E 58, E 69, F 33, J 29, J 30.

Keywords: monetary union, asymmetric shocks, stabilisation policy, wage setting, labour-market reform, equilibrium unemployment

Paper for Oxford Economic Policy Review (October 1998)

*I am grateful to Lars Ernsäter, Nils Hofvander and Kerstin Johansson at the National Institute of Economic Research for work on the simulations, to Marcus Salomonsson for research assistance, to Karin Persson for secretarial work, and to Christopher Allsopp, Jan Bröms, Nils Gottfries, Jan Herin, Luisa Lambertini, Jan-Erik Nyberg, Torsten Persson, Lars Svensson, Gisela Waisman, Lena Westerlund, Michael Woodford and an anonymous referee for comments. Agneta Carleson at the Swedish Confederation of Labour, Jan Herin and Anders Rydeman at the Swedish Employers' Federation, Christina Nordh Berntsson at Sveriges Riksbank, and Jenny Nordgren at the Ministry of Finance provided me with helpful material. 
The institutions of the EMU have been designed primarily to guarantee price stability. The perceived success of the monetary union will depend on whether low inflation is actually achieved. But it will also depend on whether the common currency proves compatible with high and stable employment. The focus here is on this issue.

There exists a vast literature on the consequences for output and employment stabilisation of giving up monetary policy independence. The key question there is the need and the possibilities to substitute other adjustment mechanisms for domestic monetary and exchange-rate policy. A much less researched issue is how monetary unification is likely to affect the average rate of unemployment over the business cycle.

My aim is not to summarise existing research. Instead, I shall focus on some aspects that have received insufficient attention, or where I disagree with the conventional wisdom.

To analyse the costs of relinquishing monetary policy autonomy, it is necessary first to ask how large the actual possibilities of pursuing an independent monetary policy will be for the EU countries that - at least for some time - stay outside the EMU (the outs). Section 1 discusses both the compatibility of exchange-rate changes with an inflation target of the type adopted by the UK and Sweden, and the external constraints that may arise from a desire to limit exchange-rate fluctuations within the EU. The conclusion is that monetary policy will be constrained, but that there will still be considerable room for exchange-rate changes in the case of country-specific demand shocks.

Section 2 relates to the discussion of whether fiscal policy can substitute for monetary policy in the EMU. This discussion has almost exclusively focused on to which extent the budget-deficit rules in the EMU may restrict the possibilities to affect the level of aggregate expenditure. This section points out that variations in payroll taxes (matched by other tax or by government-expenditure changes) may be used for expenditure-switching purposes as a direct substitute for exchange-rate flexibility. 
Such a policy need not interfere with the deficit rules, but it is likely to be only an imperfect substitute for nominal exchange-rate changes.

The last two sections analyse the probable effects of monetary union on labour-market flexibility. The starting point is that much of the discussion does not distinguish properly between effects on the variability of employment and effects on the average level of employment. Section 3 analyses whether increased money-wage flexibility can be expected to be a good substitute for exchange-rate flexibility as a means of reducing output and employment variations. The upshot is that EMU membership is likely to make money wages more flexible, but that the quantitative impact may very well be small.

Section 4 analyses instead whether the EMU is likely to strengthen the political incentives for labour-market reform to reduce structural (equilibrium) unemployment. The common argument that eliminating the exchange-rate option is bound to increase pressure for such reform, because it is made clear that there exists no alternative, is rejected. More logically consistent arguments go in different directions. On the one hand, the incentive to reduce structural unemployment might be stronger outside than inside the EMU, if there is a desire to reduce the temptation to inflate and if an accommodating monetary policy can speed up the response of employment to reform. But on the other hand, there may exist a precautionary motive for more labour-market reform inside the EMU.

\section{The scope for exchange-rate changes outside the EMU}

It is well-known that the consequences of a common currency for the possibilities to stabilise the economy depends on the type of macroeconomic shocks (see, e.g., Calmfors et al., 1997; Jansson, 1997; or Mélitz, 1997). A disturbance in financial markets is likely to be transmitted to output and employment by a floating exchange rate. A monetary union would cut off this link to product and factor markets.

The stabilisation-policy cost of a common currency arises, because domestic monetary policy can no longer be used to stabilise real shocks that are asymmetric, i.e., shocks in product and factor markets that are specific to a country. A large empirical literature 
has tried to assess the importance of such shocks. Results vary, but there is a strong presumption that such asymmetric shocks have been important in the past, especially for some countries, like the UK, Sweden and Denmark, which have all chosen to not join the EMU in the first wave (e.g., Bayoumi \& Eichengreen, 1993; Hassler, 1997; Jansson, 1997).

However, there is large uncertainty on which guide the historical patterns give for the future. The earlier freedom of countries to pursue independent monetary policies and lack of constraints on fiscal policy may have given rise to policy shocks that will not occur in the EMU. ${ }^{1}$ There is also an ongoing discussion on whether or not nominal exchange-rate changes in deregulated financial markets move in an equilibrating fashion in the case of asymmetric shocks. ${ }^{2}$

I shall not try to evaluate the literature I have referred to. Instead, I shall focus on the two more narrow questions of to which extent output-stabilising exchange-rate changes between the currencies of the outs and the euro in response to asymmetric shocks in goods and factor markets are compatible with (1) the internal constraint that follows from the adoption of a domestic inflation target, and (2) the external constraint that may arise from general pressures for exchange-rate stability within the EU. The reason for this focus is that it is often maintained that monetary policy must be the same outside as inside the EMU.

\subsection{Exchange-rate changes and inflation targets}

Both the UK and Sweden have recently shifted to a monetary policy regime of inflation targeting of the same type as was earlier adopted in, for example, New Zealand. This involves setting a quantitative inflation target for the CPI (2.5 per cent in the UK, 2 per cent in Sweden), which monetary policy seeks to achieve.

Real shocks can be either demand or supply shocks. It is obvious that an inflationtarget regime represents a severe constraint on the use of monetary policy to stabilise output in the case of an adverse supply shock (for example, a wage hike). If the central

\footnotetext{
${ }^{1}$ See, e.g., Erkel-Rousse \& Mélitz (1995), Fatás (1997) and Thomas (1997).

${ }^{2}$ See, e.g., Stockman (1988), Clarida \& Gali (1994), Canzoneri et al. (1996) and Thomas (1997).
} 
bank tries to stabilise inflation around the target, interest rates have to be raised. This aggravates the fall in output. It can only be stabilised to the extent that inflation is allowed to rise temporarily.

I shall focus here on demand shocks, where the conclusions are somewhat less obvious. Such shocks are clearly of interest, as there are several recent European examples of them, where exchange-rate changes seem to have fulfilled an insurance function (Calmfors et al., 1997; Mélitz, 1997). One case is the deep recession in Sweden in 1991-94, which followed from a large reduction of domestic demand associated mainly with a strong rise in the savings rate. Another example of a dramatic adverse demand shock is Finland at the same time, where the main impulse came instead from the fall in exports to the Soviet Union. Germany in the wake of reunification in the early 1990s is instead a clear example of a positive demand shock.

The normal way of viewing monetary and exchange-rate policy in the case of demand shocks is as a substitute for nominal price and wage flexibility. If there is a fall in domestic relative to foreign demand, and prices and wages are perfectly flexible, a stabilising depreciation of the real exchange rate (a fall in the relative price of domestic output relative to foreign output) can come about through a reduction of the domestic price level relative to the foreign one. But if nominal prices and wages are rigid, a real exchange-rate adjustment must instead be accomplished through a nominal exchange-rate depreciation. However, in an inflation-target regime there will be limits on to which extent nominal exchange-rate changes can be a substitute for nominal price and wage flexibility.

Assume first that it is possible to pursue monetary policy in such a way that the inflation target for the CPI is always met (strict inflation targeting). It is well known that interest-rate changes can affect the rate of price change for domestic goods only with a considerable time lag (e.g., Svensson, 1998). But to the extent that monetary policy influences the exchange rate, there is a direct channel of influence on CPI inflation via import prices already in the short run. 
Consider an initial situation in which the exchange rate is stable (because the rates of price change for both domestic and foreign output coincide with the domestic inflation target). Obviously, if there is no fall in the rate of price increase for domestic goods, it would not be possible to counter a recessionary demand shock by interest-rate cuts leading to an exchange-rate depreciation: because CPI inflation is a weighted average of price increases for domestic goods and price increases for imported goods, the resulting import price increases would cause consumer price increases to overshoot the inflation target.

The upshot is that nominal price and wage flexibility is a precondition for real exchange-rate changes under strict inflation targeting: nominal flexibility and exchange-rate flexibility are in this case best seen as complements (Calmfors et al., 1997). Unless price increases for domestic goods fall in the case of an adverse asymmetric shock, room is created neither for a nominal nor for a real exchange-rate depreciation. But at the same time, there is a double dividend from price flexibility, because each reduction in domestic price increases permits also a nominal exchangerate depreciation that magnifies the real exchange-rate depreciation: if there is full pass-through of exchange-rate changes to import prices, the real exchange-rate deprecation becomes equal to the reduction in the rate of price increase for domestic output divided by the weight of imports in the CPI.

The above reasoning presupposes that the central bank holds inflation constant at every point of time. This is not likely to be realistic. One reason is that the central bank will probably make a flexible interpretation of the inflation target in the case of a major shock (see, e.g., Svensson, 1998). Some leeway is provided by the practice to define a tolerance margin around the inflation target. Both the UK and Sweden allow for such a margin of $\forall 1$ per cent around the target. And a major shock could motivate at least some temporary deviation from the specified interval. Both the UK and New Zealand have explicit provisions that can be interpreted in this way. To the extent that inflation is allowed to rise in the case of an adverse asymmetric demand shock, the scope for nominal and real exchange-rate changes are, of course, widened. 
Simple rule-of-thumb calculations would seem to suggest that the magnitudes of nominal and real exchange-rate changes that are compatible with an inflation-target regime are fairly large. Assume, for example, that the weight of imports in the CPI is 0.25 , and that there is full pass-through of exchange-rate changes on to import prices. Then, for example, a fall in the rate of price increase for domestic goods of 1.5 percentage points would allow a real exchange-rate depreciation of 6 per cent without changing the rate of CPI inflation. (The fall in domestic price increases reduces CPI growth by $0.75 \times 1.5=1.125$ percentage points. So there is room for the nominal exchange rate to depreciate by 4.5 per cent, as this creates upward pressure on the CPI of $0.25 \times 4.5=1.125$ percentage points, which exactly offsets the lower price increases for domestic goods. The total real exchange-rate depreciation is the sum of the fall in the rate of price increase for domestic goods and the nominal depreciation).

If instead, a temporary increase in the rate of CPI inflation by 1.5 percentage points is allowed, and this reduces the fall in the rate of price increase for domestic goods from, say, 1.5 to 1 per cent, the nominal and real exchange-rate depreciations would be 9 and 10 per cent, respectively. (The fall in the rate of price increase for domestic output reduces CPI growth by $0.75 \times 1=0.75$ percentage points. A 9 per cent nominal depreciation increases CPI growth by $0.25 \times 9=2.25$ percentage points. The increase in CPI growth is $2.25-0.75=1.5$ percentage points. The real exchange-rate depreciation is $9+1=10$ per cent.)

To get a more complete picture of the stabilisation role that monetary policy can play in an inflation-target regime, a full-scale model is needed. KOSMOS is such a model of the Swedish economy, which is used by the National Institute of Economic Research (Konjunkturinstitutet) for forecasting and policy simulations (Johansson, 1998). The model has fairly standard Keynesian characteristics in the short run with demand-determined output. There is a long-run Layard-Nickell wage-setting relationship between the levels of real wages and unemployment (Layard et al., 1991). Important short-term features are a slow response of money-wage increases to changes in inflation, pricing-to-market behaviour especially for exports (i.e., incomplete passthrough of exchange-rate changes on to the prices charged in foreign markets), and strong demand influences on domestic output prices. 
The KOSMOS model has been used to study the effects of a large asymmetric demand shock (an increase in the savings rate of households by 10 percentage points) of the same type as occurred in Sweden in the early 1990s under three alternative monetarypolicy assumptions: (1) EMU membership (a fixed exchange rate and a fixed nominal interest rate); (2) strict inflation targeting (when no deviation from the inflation target of 2 per cent is allowed); and (3) flexible inflation targeting (the rate of CPI increase is allowed to increase to 4 per cent in the first year of the shock and to stay at 3 per cent in the subsequent year before returning to 2 per cent in the third year). ${ }^{3}$

The simulation results are shown in Figures 1-6. In the first year, there is a substantial decline in GDP (2.3 to 2.8 per cent) compared to the no-shock alternative in all the cases. The nominal exchange rate depreciates by 6.4 per cent under strict inflation targeting and by 10.6 per cent under flexible targeting. The resulting real exchangerate reductions (declines in relative export prices) are 3.5 and 5.2 per cent, respectively, compared to 0.8 per cent in the EMU case. The reason why the real exchange-rate changes are not larger outside the EMU is the strong element of pricing to market for exports. Short-term real interest rates also decline in the inflation-target cases, whereas they increase inside the EMU (this is the so called Walters effect, which arises because of the fall in domestic output prices - see Figure 5 - that occurs in this case). As can be seen, the monetary-policy responses outside the EMU represent significant offsets to the shock in years 2 and 3 . This comes mainly from higher exports (Figure 3), but also from higher investment. Under strict inflation targeting, GDP is 1 per cent higher in year 2 and 0.7 per cent higher in year 3 than in the EMU case. And when inflation is allowed to rise somewhat, the shock is more than offset.

The model simulations should be interpreted with caution. They are obviously subject to the Lucas critique that key behavioural relationships could change with EMU membership (see sections 3 and 4). In practice, it is also likely that the central bank

\footnotetext{
${ }^{3}$ The simulations have been carried out by Lars Ernsäter and Nils Hofvander at the National Institute for Economic Research (Konjunkturinstitutet). I am also grateful to Kerstin Johansson for helpful discussions about the model.
} 
will have large problems of controlling inflation in the event of a major crisis. Speculative pressures in financial markets may cause the exchange rate to depreciate by so much that there is a more significant deviation from the inflation target. Then, it will be the objective of long-term price stability rather than the short-term inflation target that acts as a constraint on the possibilities to stimulate the economy through monetary policy. To preserve its long-run credibility, the central bank may have to press down domestic aggregate demand through interest-rate rises in order to reduce future price increases for domestic goods (which can be affected only with a significant time lag). Still, the analysis suggests that an inflation-target regime is not likely to be a severe constraint on monetary policy for the non-participants in the EMU (the outs) in the case of asymmetric demand shocks, provided that there is some price and wage flexibility.

\subsection{External constraints on exchange rates}

Another possible constraint on the monetary policy of the outs is external pressures from the euro countries (the ins) to avoid exchange-rate changes that affect relative competitiveness. Formally, for outs participating in an ERM-2 arrangement with the EMU (only Denmark and Greece when the common currency is introduced in 1999), changes in central rates will be determined jointly. But also for countries with a floating rate, like the UK and Sweden today, the stipulation in the Maastricht Treaty (article $109 \mathrm{~m}$ ) that exchange-rate policy shall be treated "as a matter of common interest" applies.

At the present stage, it is difficult to judge what these formal stipulations will amount to in practice, and how much that will come out of attempts at more economic policy co-ordination within the EU. They certainly did not help prevent the strong appreciation of the pound against the future EMU currencies in 1997-98. The revaluation of the central rate of the Irish pound in the run-up to EMU in the spring of 1998 also showed a readiness to adjust nominal exchange rates when this is believed to contribute to macroeconomic stability. But one might conceive of quite different reactions against depreciations by the outs, because these are considered "beggar-thyneighbour" policies (Gros \& Thygesen, 1998). However, the exchange-rate turbulence 
of the early 1990s provided a clear demonstration of the impossibility of resisting market pressures for exchange-rate changes in the case of large macroeconomic imbalances. The ERM-2 agreement bears witness of this lesson in several respects: the large fluctuation bands, the provisions that the central banks can suspend foreignexchange interventions if these "were to conflict with their primary objective" of maintaining price stability, and the understanding that adjustments of central rates should be "conducted in a timely fashion so as to avoid significant misalignments".

The possibility exists that a depreciating EU member state could be "punished" by the other states in other areas of European co-operation (Calmfors et al., 1997). This risk might be larger with the EMU than before, because the Euro-11 Council provides a forum that facilitates co-ordination of such actions. This argument bears some resemblance to the discussion that what is perceived as "competitive depreciations" may provoke protectionist measures threatening the single market (Gros \& Thygesen, 1998). But it should be acknowledged that the traditional argument for exchange-rate flexibility was exactly the opposite one, namely that protectionist measures were likely to be triggered when macroeconomic imbalances could not be addressed through exchange-rate adjustments (Friedman, 1953; Johnson, 1970).

One can conceive both of situations where a depreciation by an out could provoke negative reactions from the ins and of situations where it is likely to be welcomed. The former case might arise if all the EU countries are hit by a deep recession, even if the out is hit more severely. But it is difficult to understand why the ins would oppose an exchange-rate change, if they find themselves in a boom and the economy of the out is in a deep recession (compare the case of Germany vis-á-vis the rest of the ERM in 1991-93).

Somewhat paradoxically, the uncontrollability of exchange rates in deregulated financial markets may make exchange-rate changes in the case of asymmetric demand shocks more acceptable. If the perception is that erratic market expectations move the exchange rates in such situations, it would make little sense to try to press individual

\footnotetext{
${ }^{4}$ Resolution of the European Council on the establishment of an exchange-rate mechanism in the third stage of economic and monetary union (1997).
} 
countries to change their monetary policies to stabilise exchange rates once large macroeconomic imbalances have developed. So my conclusion is that external pressures from the EMU countries are unlikely to impose significant constraints on exchange-rate changes for an out hit by a large asymmetric demand shock. The exception would be the need to observe exchange-rate stability within the ERM during the two years preceding entry into the EMU, once such a decision is taken. However, there is considerable uncertainty also regarding how strict the requirements on this point will prove to be in the end: for both Finland and Italy, a flexible interpretation of the ERM criterion for EMU membership was made, and it is often maintained that ERM membership might be politically impossible in the UK in view of past failures with fixed exchange rates (Thygesen, 1995; Gros \& Thygesen, 1998).

\section{An expenditure-switching fiscal policy}

A widely discussed issue when judging the consequences of the EMU is whether fiscal policy can act as a substitute for an independent monetary policy. This discussion has focused almost exclusively on to which extent the rules on excessive deficits in the Maastricht Treaty and the Stability and Growth Pact constrain fiscal policy as a stabilisation tool (see, e.g., Buti et al., 1998; Eichengreen \& Wyplosz, 1998; Gros \& Thygesen, 1998; and Thygesen, 1998). The interest is then in how the level of aggregate spending in the economy can be affected. But there is also the possibility that fiscal policy could aim at switching expenditures between foreign and domestic output, just as an exchange-rate change does. To the extent that this would involve changes in the structure of taxes and government expenditures but not in deficits, the fiscal rules in the EMU would not place any obstacles. By and large, this policy option has been neglected in the EMU discussion, although it has received some attention in the Nordic countries.

A first possibility is to "twist" government expenditures in the direction of domestic employment as discussed by Andersen (1997). Government consumption (employment) can be increased in a recession at the same time as income taxes are raised or income transfers to households reduced, so that the overall fiscal balance is 
left unchanged. ${ }^{5}$ This will tend to raise overall employment for balanced-budgetmultiplier reasons: there will be a net stimulative effect because the whole first-round increase in government expenditures results in new hires, whereas part of the reduction in real indisposable income for households is absorbed by lower savings and imports. An argument against such policy is that it may be difficult to achieve large short-run variations in employment this way, because of the inertia involved in publicsector employment decisions. Another argument against the policy is the risk of ratchet effects leading to a permanent expansion of the public sector and crowding-out of private-sector employment (Söderström \& Viotti, 1978; Calmfors, 1982; Calmfors \& Horn, 1986).

\subsection{Variations in payroll taxes as a method of "internal" exchange-rate change}

The most direct substitute for nominal exchange-rate changes is what has been labelled internal exchange-rate changes in the Scandinavian policy debate (Andersen, 1997; Calmfors et al., 1997; Boldt, 1998). The idea is to use variations in payroll taxes paid by employers to change the real exchange rate. This can be done without affecting the overall fiscal balance if other taxes or if government expenditures are changed at the same time in a compensating way. For example in a recession, the real exchange rate can be depreciated through a cut in the payroll tax rate. The effects on the government budget can then be neutralised by a rise in employee contributions to the social security system, in income taxes or in the VAT. Government transfers to households can also be reduced (but it is less appropriate to reduce government consumption for the balanced-budget-multiplier reasons discussed above)

There are some experiences of internal exchange-rate changes in the Scandinavian countries. Denmark made such an internal devaluation in 1988 in order to improve competitiveness without having to change the exchange rate within the ERM system. Another example is Sweden in 1993 towards the end of the deep recession, when a small payroll tax cut was financed by a rise in the VAT.

\footnotetext{
${ }^{5}$ Saint-Paul (1998) produces some (weak) evidence that variations in government consumption have indeed been used in this way in France and Italy
} 
The neglect of the possibility of internal exchange-rate changes in the EMU discussion is surprising, because the high payroll taxes make it a viable policy option in most EU countries. Table 1 shows that payroll tax rates for blue-collar workers are above 40 per cent in Italy, and between 30 and 40 per cent in Austria, Belgium, France, Sweden and Spain. They are between 20 and 30 per cent in Finland, Germany, Greece and Portugal. The main outlier is Denmark, where there are basically no such taxes. The UK and Ireland also have low payroll tax rates (around 10 per cent). 
Table 1. Payroll tax rates in the EU countries in 1998

\begin{tabular}{|l|c|c|}
\hline \hline & Blue-collar workers & White-collar workers \\
\hline Austria & 31.9 & 25.2 \\
Belgium & 37.7 & 34.9 \\
Denmark & 1.7 & 1.0 \\
Finland & 24.6 & 24.6 \\
France & 39.0 & 36.2 \\
Germany & 22.4 & 17.6 \\
Greece & 28.0 & 28.0 \\
Ireland & 12.0 & 11.2 \\
Italy & 45.8 & 43.0 \\
Luxembourg & 15.3 & 12.9 \\
Netherlands & 17.3 & 10.9 \\
Portugal & 24.5 & 24.5 \\
Spain & 33.0 & 33.0 \\
Sweden & 33.0 & 33.0 \\
UK & 10.0 & 10.0 \\
\hline
\end{tabular}

Note: The payroll tax rates for blue-collar workers have been computed as the tax rates for the average wage for production workers in manufacturing and the payroll tax rates for white-collar workers as the tax rates for double this wage.

Source: Swedish Employers' Federation.

It is straightforward to show that a cut in the payroll tax rate at an unchanged fiscal balance will have similar output and employment effects as a nominal exchange-rate depreciation in a short-run macro model with a fixed capital stock (Calmfors, 1993). The logic is the same as for the standard proposition that a devaluation is equivalent to an export subsidy financed by an import tax. With a fixed money wage, a cut in the payroll tax lowers the ratio between the nominal domestic wage cost and foreign prices in domestic currency in the same way as a nominal exchange-rate depreciation. If the direct aggregate-demand effects are neutralised through accompanying changes in other taxes and government expenditures (which do not fall on employers), the consequence is a depreciation of the real exchange rate (the relative price between domestic and foreign output).

One might think that such tax restructuring to depreciate the real exchange rate cannot work, because the increased taxes (or reduced transfers) for employees would be 
shifted on to wages, so that labour costs are left unchanged. This could be so. But the argument must be put in context. If the starting point is that relinquishing monetary policy independence has a potential cost, because rigid money wages imply that nominal exchange-rate changes have real short-term effects, then the same logic requires that an internal exchange-rate change should have real short-term effects as well. Neither internal nor "external" exchange-rate changes can work unless real wages are cut.

The parallel between internal and external exchange-rate changes is must clear cut when a reduction in payroll taxes is financed by an increase in the VAT, because the main direct effect for employees is in both cases a rise in the CPI resulting from an increase in import prices (for domestic output prices, a higher VAT and a lower payroll tax more or less cancel out). In practice, the room for VAT changes may be limited, because substantial differences in VAT rates between EU countries would create opportunities for cross-border trade to exploit the possibilities of tax arbitrage. So financing via higher employee contributions to the social security system, higher income taxes or lower government transfers to households might be more probable. But a similar reasoning applies in these cases, too, as long as one believes that the important nominal rigidities concern pre-tax nominal wage rates and not after-tax nominal disposable incomes. This belief is consistent with existing theories of wage stickiness (see section 3).

\subsection{The pros and cons of internal exchange-rate changes}

The question is how good a substitute internal exchange-rate changes are for external exchange-rate changes. Here, several considerations are relevant.

A first aspect concerns the political economy of internal exchange-rate changes. One should expect it to be politically much more difficult to agree on an internal exchangerate change than on an interest-rate cut in order to achieve a depreciation. Fiscal policy is in general characterised by a slower decision-making process than monetary policy. Moreover, if payroll taxes are to be cut to achieve an internal devaluation, political agreement must be reached on which other taxes and charges to be raised and which government expenditures to be lowered. Because the choice has income-distribution 
consequences, the political complications are obvious. The difference in political complexity between decisions on internal exchange-rate changes and on monetary policy is further exacerbated to the extent that monetary policy has been "depoliticised" through delegation to an independent central bank. Lastly, any decisions on tax scales and transfer systems are much more technically complex than a decision on the short-term interest rate. It follows that an internal exchange-rate change is likely to take time and to be of limited size.

These political constraints on internal exchange-rate changes can be seen both as an advantage and a disadvantage. The political inertia reduces the risk that the instrument should be misused. Internal exchange-rate changes would not seem likely to be used for fine-tuning purposes but rather as an insurance against large shocks. The disadvantage is that policies may take a long time to react. Sweden in the deep downswing of 1991-92 provides an example of this. An internal devaluation was discussed for a long time as the recession worsened, but a small internal devaluation to be effected from January 1, 1993 was not decided until late in the autumn of 1992. A major internal devaluation was not announced until the very morning of the day when the Swedish central bank had to abandon the peg of the crown (November 19, 1992) as a last unsuccessful attempt to avoid this (and was therefore never implemented). ${ }^{6}$

Another important aspect is that the "political system" has direct control over the size and timing of an internal exchange-rate change, whereas the size and timing of nominal exchange-rate changes are to a large extent determined by the financial markets. Again, this may be viewed both as an advantage and a disadvantage. The advantage is that unwarranted real exchange-rate changes driven by market expectations and overshooting phenomena can be avoided. The disadvantage is that markets might sometimes perceive the need for real exchange-rate changes better than politicians. I would claim that this held true at least for some EU countries in the early 1990s. Finland and Sweden (where unemployment rose by nearly 15 and 7 percentage points, respectively) are good illustrations.

\footnotetext{
${ }^{6}$ The Swedish discussion on an internal devaluation has been described in Calmfors (1996).
} 
A third difference between internal and external exchange-rate changes concerns inflation. Because the common monetary policy in the EMU ties down long-run inflation in the individual member country, there is no risk that an internal devaluation within the EMU triggers a long-run inflationary spiral. The political difficulties of agreeing on large changes in the tax/expenditure structure (and the ultimate limit set by the fact that payroll tax rates cannot be reduced below zero and that general employment subsidies are improbable) should also imply a small risk in the medium term that wage setters become more aggressive because they would expect moneywage increases to be accommodated through payroll tax cuts (Persson, 1996). Rather, it is likely to be realised that if the government wants to retain internal devaluations as a countercyclical instrument, room for this must be created through internal revaluations (i.e., increases in payroll taxes and cuts in other taxes or fees) in booms.

In the short run, an internal devaluation financed by government-expenditure reductions or increases in other taxes than the VAT would even reduce domestic inflation, because the reduction in payroll taxes would exert downward pressure on the prices of domestically produced goods. To the extent that this causes a temporary increase in the short-term real interest rate, the stimulative effect of the real exchangerate depreciation is weakened.

An interesting example of how the idea of internal exchange-rate changes could be applied in practice has recently been provided in Finland. To facilitate macroeconomic stabilisation inside the EMU, the central labour-market organisations have concluded an agreement on so called "buffer funds" to help finance unemployment insurance and pensions. ${ }^{7}$ The idea is to build up such funds in good years, so that one can draw on them in recessions and thus avoid raising employer contributions then (and possibly also lower them). The funds are planned to be of limited size - the order of magnitude is 1 per cent of GDP - but the explicit motivation is to allow some flexibility in wage costs without having to reduce actual nominal wages (Boldt, 1998). 7 Avtal om principerna för hur ändringar $i$ arbetspensionsförsäkrings-
arbetslöshetsskyddsavgifterna skall utjämnas vid konjunkturväxlingar (1997). 
A system like the Finnish one is likely to do away with some of the political inertia associated with internal exchange-rate changes which follows from the need to agree on changes in other taxes or in government expenditures. Moreover, if payroll tax cuts are financed by running down the buffer funds rather than by rises in other taxes or reductions in government expenditure, the stimulative effect will be larger, because there will also be an aggregate expenditure increase in addition to the expenditureswitch effect. This amounts to the same thing as running an ordinary government budget surplus in good times in order to create room for payroll tax reductions in bad times. It is noteworthy that the labour-market organisations themselves have chosen to administer the funds in Finland: they will not therefore form part of the government sector and will not be encompassed by the fiscal rules in the EMU. This means larger freedom in using them: they can be run down without any risk of conflict with the 3 per-cent-of-GDP limit for government deficits.

My conclusion is that variations in payroll taxes (internal exchange-rate changes) can be used as a substitute for monetary policy in the case of asymmetric shocks inside the EMU. But the substitute is likely to be an imperfect one for both political-economy reasons (the decision inertia) and for economic reasons (higher real interest rates in downswings). At the same time, internal exchange-rate changes may involve smaller risks than "external" exchange-rate changes.

\section{EMU and money-wage flexibility}

Because the introduction of the euro represents a major economic-policy regime shift, the Lucas critique is highly relevant: key behavioural relationships could change, so that past experience may offer little guide when analysing the likely consequences of the EMU. A common claim is that wage discipline will increase and make the labour market more flexible (e.g., Mélitz, 1997; Pissarides, 1997). However, this discussion often confounds different aspects. One important distinction is between, on the one hand, the cyclical sensitivity of the economy and, on the other hand, equilibrium unemployment (average unemployment over the business cycle). The first aspect has to do with the flexibility of money wages, the second with the average level of real wages (and their distribution). The two issues should be kept apart, because there is 
much to suggest that the causes of short-term money-wage rigidity and of permanently high real wage levels (and relative-wage distortions) are different.

A second important distinction derives from the way through which the wage-setting process could be changed by the EMU. The change can come about either as a direct response of wage setters to the switch in monetary policy regime (a direct market response) or as an indirect response because governments are induced to legislate changes in labour-market institutions (which is an issue of political economy).

My first question is to what extent exchange-rate and money-wage flexibility are substitutes, so that one can expect the elimination of exchange-rate flexibility between the members of the EMU to be compensated by increased money-wage flexibility. The main problem when trying to answer this question is the unsatisfactory state of knowledge in general regarding the reasons for money-wage inertia. There exists no generally accepted explanation of why money wages are inflexible.

To organise thinking, it is helpful to distinguish between two different types of money-wage rigidity. A first type arises because money wages are set for fixed contract periods, during which they are not changed even if unforeseen events occur. A second type of stickiness is when money wages (or the rate of money-wage growth) are not changed even though new labour contracts are negotiated. The latter type of money-wage rigidity is usually associated with resistance to money-wage cuts (or to very low money-wage increases).

\subsection{Money-wage rigidity and long contract periods}

Theories of contract length emphasise the costs of wage negotiations. These costs are likely to be of far greater magnitude than the "menu costs" that have been stressed as an explanation of price rigidity: the wage bargaining process consumes scarce time of both firm managers and union officials, it may upset labour-management relations, and there is the ultimate risk of a costly labour-market conflict. The optimal choice of contract length involves a trade-off between these costs and the costs in terms of additional variations in output, employment and profits that arise when wages cannot be adjusted to unanticipated events during the contract period (Ball, 1987; Ball et al., 
1988). It is well-known that long contract periods lead to particularly large aggregate nominal wage rigidity if bargaining is decentralised and unsynchronised. With overlapping wage contracts, the money wages negotiated in new contracts is to a large extent tied down by a desire to avoid large deviations from wages in already existing contracts (Taylor, 1980; Blanchard, 1986).

If EMU membership leads to larger demand shocks because country-specific disturbances can no longer be stabilised by monetary policy (or because the common monetary policy affects the various member economies differently, as recently stressed by Ramaswamy \& Sloek, 1997, and Dornbusch et al., 1998), the models of optimal contract length give a clear-cut conclusion. Because the marginal cost of longterm wage contracts increases with greater variability in demand, there is an incentive to reduce contract length. This would make money wages more flexible. At the same time, the increase in flexibility is not likely to be large enough to prevent output (employment) variability from increasing. The logic is the following. An individual firm will reduce the length of its wage contracts only if the variability in the demand for its products increases. If other firms were to increase the flexibility of their money wages by so much that variability in aggregate demand, and thus also the variability in product demand for the individual firm, remains unchanged, then the individual firm has no longer any incentive to reduce the length of its wage contracts. Hence, if all firms are alike, an increase in money-wage flexibility which is so large as to prevent output (employment) variability from increasing cannot be an equilibrium.

The qualitative conclusion that larger demand shocks should increase money-wage flexibility does not tell whether the quantitative effects are likely to be big or small. A possible reason for why the quantitative effects of EMU membership on contract length may be limited is the existence of externalities: part of the benefit to society of a shorter wage contract in a firm accrues to the rest of the economy, because the aggregate-demand fluctuations that affect all firms are reduced (Ball, 1987). ${ }^{8}$ This intuition of limited effects is confirmed by the numerical examples in Ball et al.

\footnotetext{
${ }^{8}$ As discussed by Ball, there may also be a negative externality because shorter contracts increase the variability of the real wage in each firm. The reason is that the aggregate price level becomes more volatile when wages can be changed more frequently.
} 
(1988). They ask the question how increased demand variability will affect real output variability when one takes the endogenous response of the length of wage contracts into account. According to their model, for example, an increase in the standard deviation of nominal GNP growth from 3 per cent (roughly the relevant figure for the post-war period in the US) to 5 per cent, would at a 2 per cent rate of inflation only reduce the effect on real output of a 1 per cent change in demand from 0.47 to 0.41 per cent. This implies that the "net" increase in output variability is around 70 per cent of the "gross" increase in demand variability. ${ }^{9}$

Another consideration concerns the distinction between insiders and outsiders in the labour market. With low and stable inflation, long-term wage contracts also lead to stable and predictable real wages. Employed insiders with little unemployment risk may therefore have a strong preference for long-term wage contracts even if this entails larger employment variability: the costs of this will mainly fall on other groups (outsiders) with weaker affiliation to the labour market (Gottfries, 1992). To the extent that insiders dominate wage setting, this is likely to reduce the impact on money-wage flexibility of EMU membership.

\section{2. Downward money-wage rigidity}

A second type of rigidity arises if there is resistance to money-wage changes, viz. money-wage cuts, in general, so that there are difficulties of adjusting money wages also when new wage contracts are negotiated. Here, there exist several attempts at explanation.

A first type of reasoning emphasises co-ordination failures. A widely quoted formulation is due to Keynes (1936). He argued that the concerns of employees over relative wages would make them oppose money-wage reductions, unless all wages could be cut simultaneously so as to preserve existing wage differentials. Because such co-ordination is difficult, nominal wages tend to be rigid downwards.

\footnotetext{
${ }^{9}$ In the example, the standard deviation of demand increases with $0.05 / 0.03-1=67$ per cent. The increase in the standard deviation of real output is $0.05 \times 0.41 / 0.03 \times 0.47=46$ per cent. Thus, as much
} 
A modern version of the co-ordination-failure argument has been advanced by Ball $\&$ Romer (1991). They stress how the benefit of changing the wage (price) in an individual firm depends on whether other firms do the same ("strategic complementarity"). With small demand shocks, wage adjustment costs may make it unprofitable for each firm to change the wage independently of what happens in other firms. With very large shocks, it will always pay to adjust the wage even if others do not. But for shocks of intermediate size, there may be a net gain for the individual wage setter to adjust only if others do the same. This gives rise to multiple equlibria.

A second type of explanation considers explicitly the bargaining game between employers and employees (Holden, 1994; 1997). It notes that open labour-market conflict is not the only alternative to agreement on a new wage contract. Instead, the common practice is almost everywhere that production continues with the same money wage as in the old contract until a new one is concluded. In some countries, such "hold-out" is a legal stipulation, in others it is a social convention. Holden (1994) shows that the consequence may be nominal wage rigidity: if there is only a moderate change in nominal demand relative to the earlier wage, it will pay neither for unions nor for employers to initiate a labour-market conflict to change the wage. In principle, this could lead to both upward and downward money-wage rigidity. But there could be a bias towards downward stickiness if employees have larger possibilities than employers of inflicting damage on the other party during a hold-out. This is the case if employees can reduce output by working to rule or lowering effort in other ways, whereas the employer is obliged to pay out the earlier money wage. If so, the earlier money wage works as the fall-back position of workers in bargaining, with the consequence that it may always be possible for them to achieve some money-wage growth (Holden, 1997).

A third psychological line of argument stresses instead how money-wage cuts conflict with social norms about fairness. Firms do not cut money wages because this would have a negative impact on morale and reduce productivity (Solow, 1979; Akerlof, 1982; Akerlof \& Yellen, 1990). This reasoning is regarded by many economists as 
problematic, because no ordinary rational-behaviour explanation is provided of the social norms themselves. However, it is hard to sidestep the ample survey evidence that employers do perceive such a link between money-wage cuts and productivity (e.g., Blinder \& Choi, 1990; Bewley, 1995; Agell \& Lundborg, 1995; Campbell and Kamlani, 1997). In the words of Bewley (1998), "workers interpret pay cuts as insults, even if everyone's pay is cut, because the practice of rewarding effort and loyalty through pay increases leads people to associate them with appreciation of their worth to the company". Even though lay-offs may also be associated with adverse morale effects, these may be smaller and more short-lived, because "they get the misery out of the door" (Bewley, 1998).

It is more difficult to predict how the general type of money-wage rigidity that I discuss in this section should be affected by EMU membership than the rigidity following from long contract periods. According to both the co-ordination-failure model of Ball \& Romer (1991) and the hold-out model of Holden (1994), there will be more cases with wage adjustments if macroeconomic shocks become larger. The incentive for co-ordination would also be stronger with larger shocks, although we have little knowledge about the determinants of the degree of co-ordination of wage bargaining. Ball \& Romer (1991) suggest that the most important factor may be history rather than "the underlying natures of economies".

It is probably the most difficult to predict how the EMU will affect money-wage flexibility if one adopts the psychological line of argument. The cost of resistance to money-wage cuts will, of course, be greater if the EMU means larger net shocks for the individual country. But because we cannot explain the development of social norms, any discussion of the likely effects is highly speculative. A possible conjecture is that the change in the extent of macroeconomic fluctuations would be too small to "rock" established norms. Such a judgement would receive some support from the experiences that money-wage cuts are regarded as acceptable only when shocks are so large that the survival of the individual firm is threatened (Agell \& Lundborg, 1995; Bewley, 1998). One could also conjecture that any changes in social norms take a long time to occur. If one instead adopts the Holden (1997) explanation of money wages in 
earlier contracts as a floor (because they determine the fall-back position of workers in new negotiations), there seems to be little reason to expect the EMU to change this.

\subsection{Economic policy and money-wage rigidity}

My discussion has so far dealt with the market responses of wage setters. Another issue is whether government policy can contribute to more money-wage flexibility. As discussed in section 3.1, there would exist an incentive for government action to the extent that the social benefits of more money-wage flexibility in the EMU outweigh the private benefits to wage setters. But the insufficient understanding of the causes of money-wage rigidity makes it difficult to prescribe appropriate action.

One possible role for governments might be to co-ordinate expectations by formulating and communicating wage norms to employers and unions. This would amount to a loose form of incomes policy and has been tried in various forms in different countries. One example is the so called Rehnberg Commission in Sweden, which in the deep downswing of 1991-92 was given the task of trying to decelerate money-wage growth and synchronise contract periods (Calmfors et. al, 1997). There exists, however, no econometric evidence suggesting a larger fall in money-wage increases in those years than can be explained by the rise in unemployment (Forslund, 1995; Holden \& Nymoen, 1998; Rödseth \& Nymoen, 1998). Needless to say, such attempts at co-ordination do not appear a policy option in countries with very decentralised bargaining systems, such as the UK.

Profit sharing can be seen as a way of inducing more money-wage flexibility to the extent that it makes a fraction of employee compensation variable. Such arrangements can be stimulated by taxing profit shares at lower rates than ordinary wage income or giving tax breaks to employee stock ownership plans (as in the UK and the US). But the schemes must be constructed in such a way that mere reclassification of what is really fixed money wages to reap the tax benefits is avoided.

It is less clear to which extent labour-market reform of the type that has been proposed to reduce European structural unemployment, such as less generous unemployment benefits (see section 4), can affect money-wage rigidity. Models of this have not yet 
been worked out. But one could conjecture that there might be such an effect. For example, in the models of optimal contract length, the cost of employment reductions (to employees) should be larger, the less generous are unemployment benefits. This should strengthen the incentive for short contract periods to reduce employment variations. $^{10}$

\subsection{Empirical observations}

There is little empirical knowledge that can be brought to bear on the issue of moneywage flexibility in the EMU. But a few observations can be made.

Although the US represents a currency union (and has the type of deregulated labour market that is usually proposed as a remedy for the high unemployment in the EU), most studies have found a higher degree of nominal wage stickiness than in Europe (e.g., Grubb et al., 1983; Bruno \& Sachs, 1985; Layard et al., 1991; Ball, 1994). Union wage contracts tend to be long-term (often three-year) and overlapping. Typically, one also finds a bunching of nominal-wage increases for individuals around zero, which is consistent with an important degree of downward money-wage rigidity (e.g., Card \& Hyslop, 1996; Akerlof et al., 1996).

A possible reason for smaller nominal wage flexibility in the US than in Europe could be that asymmetric demand shocks are smaller. Indeed, Bayoumi and Eichengreen (1993) found this to be the case, but the difference was small. Another possible reason could be the existence of other adjustment mechanisms that can substitute for moneywage flexibility, viz. high labour mobility. But this argument is not consistent with the finding that regional price adjustments seem to play a very small role inside countries like Germany and Italy (and Canada) with low degress of labour mobility (Obstfeld \& Peri, 1998). So the upshot is that the US case would seem to warn against too large optimism regarding money-wage flexibility in the EMU.

\footnotetext{
${ }^{10}$ The flip side of the argument is that low unemployment benefits also increase the gain from employment increases. But to the extent that wage setting is dominated by employed insiders, one would expect this effect to be of less importance for contract length than the effect of a larger cost of employment decreases.
} 
Another observation is that it has not been possible to establish any strong links between the amount of nominal shocks and indications of nominal wage flexibility. Layard et al. (1991) find only a weak such association for the OECD countries. Ball et al. (1988) use a larger sample of countries, but the data reject their theoretical proposition that a shock of given size is associated with smaller real output effects when nominal GNP growth is more variable.

The European experiences of the last two decades give some examples where countries that have pegged their currencies to the German mark have achieved very low rates of nominal wage growth also in comparison to Germany (Austria, Belgium, the Netherlands, and France). But not even in Belgium and the Netherlands, where wage moderation has been the most pronounced, have the annual rates of earnings growth in any single year fallen below 1 per cent (Figure 7). In Austria and France, the lowest rates of nominal wage increase have been between 3 and 4 per cent (Figure 8). Moreover, for most EU countries (with the exception of Italy), the constraints on exchange-rate changes imposed by ERM membership did not seem to reduce the unemployment costs of bringing down inflation in the 1980s (Egebo \& Englander, 1992).

An interesting example is provided by Finland, where the central labour-market organisations came very close to agreeing on nominal wage reductions across the board in the deep recession of 1991. These wage cuts were never implemented, because speculation against the Finnish mark triggered a depreciation when one of the major trade unions began to voice concerns over the agreement. There are different ways to read this experience. One is that a centralised wage-setting system may indeed be capable of delivering nominal wage reductions, if a single currency would rule out the possibility of nominal exchange-rate depreciations. Another interpretation is that the incentives for some party to renege on such co-ordination cannot be resisted even in such an extreme recession as occurred in Finland, when unemployment rose from 3.5 per cent in 1990 to 18.4 per cent in 1993 .

However, it should be noted that the labour market organisations in Finland have explicitly ruled out future nominal wage cuts in a joint declaration on the EMU, even 
though they show a high degree of awareness of the risk of asymmetric shocks (because of the large importance of the forest sector in the Finnish economy). ${ }^{11}$ But at the same time, unions and employers have agreed to promote profit-related pay and the establishment of "personnel funds" at the company level in order to increase the flexibility of wage cost in the EMU. ${ }^{12}$ Similarly, Swedish trade union economists have expressed an interest in profit-sharing arrangements at the national level as a way of preparing EMU membership. ${ }^{13}$ This may suggest that it could be easier to achieve increased nominal wage flexibility through the ex ante establishment of an institutional system for contingent pay than through ex post negotiations on ordinary wages.

An important observation is that profit-related pay involves different trade-offs than the choice of optimal contract length (see section 3.1). Once the system is set up, there should be no bargaining costs such as when a new wage contract is negotiated, but the variability of real compensation for insiders is likely to be larger from profit sharing than from more short-term wage contracts to the extent that reductions in total compensation are allowed. It is also possible that profit sharing leads to higher productivity and thus to higher average real wages over the business cycle (Freeman, 1998).

In sum, there are some good arguments why EMU membership could lead to more money-wage flexibility. But there is genuine uncertainty on how quantitatively important the impact is likely to be. It can very well be that the effect of EMU membership on nominal wage flexibility will be overshadowed by the effect of much lower inflation than in the past. The reason is that inflation may be a much more important determinant of money-wage flexibility than the amount of demand shocks.

There are at least two reasons to expect lower inflation to reduce money-wage flexibility. First, to the extent that downward money-wage rigidity is important, the

\footnotetext{
11 Ställningstagande till den Europeiska Ekonomiska och Monetära Unionens inverkan på verksamhetsprinciperna på arbetsmarknaden (1997). Nominal wage decreases are also denounced in, for example, a background paper from the Finnish Confederation of Labour, which discusses the possibility of internal exchange-rate depreciations (Boldt, 1998).

${ }^{12}$ Personalfonder samt andra frivilliga EMU-buffertar på företagsnivå (1997).
} 
fact that low inflation means only a small distance (productivity growth plus inflation) to zero money-wage growth provides an important restriction. Second, low inflation means an incentive for longer wage contracts, because money wages then need to be adjusted less frequently and the variability of inflation is likely to be smaller. Indeed, Ball et al. (1988) found strong empirical support for the hypothesis that low inflation increases the real output effects of nominal shocks, which is indicative of reduced money-wage flexibility, whereas they could find no effect of changes in the amount of demand fluctuations. Fregert (1994) finds that wage contracts in Sweden have become shorter during periods of high and variable inflation.

Table 2 illustrates the determinants of money-wage flexibility by comparing the recession of the early 1990s with the preceding boom in a number of EU countries. The largest decelerations of money-wage growth occurred in the "soft-currency" countries where currency depreciations relative to the German mark took place (Finland, Italy, Spain, Sweden and the UK). As these countries were the ones with the highest initial rates of money-wage growth, the picture is consistent with the hypothesis that the rate of inflation - rather than the monetary policy regime - is crucial. It is true that unemployment increases were much larger in Finland, Spain and Sweden than in most of the other EU countries, but this does not apply to the UK (where the unemployment increase was of similar magnitude as in Belgium, France and Germany) or to Italy (where unemployment actually fell). One crude way of controlling for the differences in unemployment increases is to look at the sacrifice ratio - the ratio between the increase in unemployment and the reduction in moneywage growth. ${ }^{14}$ There appears to be no relationship between monetary policy regime and the sacrifice ratio: the ratio is highest in Germany (a hard-currency country) and in Spain and Finland ("soft-currency" countries), and lowest in the UK (a "softcurrency" country) and Austria (a hard-currency country).

Table 2: Nominal wage growth and unemployment in selected EU countries

\begin{tabular}{|l|l|l|l|}
\hline \hline & Average earnings growth & Average unemployment & Sacrifice \\
\hline
\end{tabular}

\footnotetext{
${ }^{13}$ Ekonomiska Utsikter (1998).

${ }^{14}$ The sacrifice ratio is not computed for Italy, where money-wage growth fell despite a fall in unemployment, and the Netherlands, where money-wage growth increased despite a rise in unemployment.
} 


\begin{tabular}{|l|ccc|rrr|c|}
\hline \hline & $1988-91$ & $1992-95$ & Change & $1988-91$ & $1992-95$ & Change & ratio \\
\hline Austria & 5.3 & 4.6 & -0.7 & 3.3 & 4.1 & 0.8 & 1.1 \\
Belgium & 4.4 & 3.2 & -1.2 & 9.4 & 11.8 & 2.4 & 2.0 \\
Finland & 8.3 & 3.4 & -4.9 & 4.7 & 16.4 & 11.7 & 2.4 \\
France & 4.7 & 3.5 & -1.2 & 9.4 & 11.6 & 2.2 & 1.8 \\
Germany & 5.3 & 4.5 & -0.8 & 6.8 & 8.8 & 2.0 & 2.5 \\
Italy & 8.8 & 5.3 & -3.5 & 11.7 & 11.1 & -0.6 & - \\
Netherlands & 2.4 & 2.8 & 0.4 & 6.5 & 6.7 & 0.2 & - \\
Spain & 7.6 & 5.6 & -2.0 & 17.3 & 22.3 & 5.0 & 2.5 \\
Sweden & 8.0 & 4.4 & -3.6 & 1.8 & 7.1 & 5.3 & 1.5 \\
UK & 8.7 & 5.1 & -3.6 & 7.0 & 9.4 & 2.4 & 0.7 \\
\hline
\end{tabular}

Note: The sacrifice ratio is the ratio between the increase in unemployment and the reduction in earnings growth.

Source: OECD

\section{EMU and equilibrium unemployment}

The degree of money-wage flexibility matters for the size of output and employment fluctuations. Another issue is the relationship between EMU and equilibrium unemployment, i.e., the average rate of unemployment around which the cyclical fluctuations occur. In view of the consensus that the high European unemployment is largely structural (see, e.g., OECD, 1994; Nickell, 1997; or Elmeskov et al., 1998), this issue is a highly relevant one.

My point of departure is that equilibrium unemployment is determined mainly by the institutions in the labour market and that it can be reduced by well-designed labourmarket reform. This could involve, for example, reductions of the level and duration of unemployment benefits, more effective active labour-market policy, substitution of individual for collective wage agreements, lower minimum wages for young people, changes in the legal framework for wage setting with the aim of increasing the relative bargaining strength of employers (like restrictions on the right to strike), and possibly also reductions in employment protection and in taxes. ${ }^{15}$ The reason why such reforms are not implemented is political constraints. The reforms may not be considered to be

\footnotetext{
15 Although there is an ongoing discussion on the exact impact of various measures, there is a surprisingly large overlap between different judgements on which reforms that might reduce structural unemployment - although not always on their desirability when the trade-offs with respect to other goals are considered (see, e.g., OECD, 1994; Lindbeck, 1996; Layard \& Nickell, 1997; Nickell, 1997; Calmfors et al., 1998; and Elmeskov et al., 1998).
} 
in the interest of the political majority, or they may be blocked by various minorities. First and foremost, employed insiders are likely to oppose reform that lower their real wages (Saint-Paul, 1995, 1996). Insiders also have an interest in limiting exposure to unemployment through job protection legislation (Saint-Paul, 1993) and in mitigating the consequences of job loss through generous unemployment insurance (Saint-Paul, 1996). The already unemployed have, of course, an even larger interest in generous unemployment benefits (Wright, 1986; Orszag \& Snower, 1998). For these reasons, labour-market reform to reduce equilibrium unemployment will have large political costs for any government and may threaten the cohesion of existing coalitions both within and between political parties.

When discussing the impact of the EMU on the political incentives for labour-market reform, I shall make the key assumption that labour-market institutions continue to be an area for largely national decision-making. It is true that the Amsterdam Treaty stipulates that the EU member states shall "work towards developing a coordinated strategy for employment" (article 125) and that the ECOFIN Council "shall each year draw up guidelines which the Member States shall take into account in their employment policies" (article 128). The Council will examine the employment policies of each member state and can make recommendations. But at the same time, it is made clear that co-operation does "not include harmonisation of the laws and regulations of the Member States" (article 128) and that "the competences of the Member States shall be respected" (article 127). ${ }^{16}$ The Council of the European Union Resolution on the 1998 Employment Guidelines also makes it clear that "they must respect the principle of subsidiarity and Member States' responsibilities with regard to employment" and that "the differing situation of the Member States" will "result in differing solutions and emphases".

Only future can tell how the stipulations in the Amsterdam Treaty will be interpreted in practice. But co-ordinated labour-market reform is likely to be very difficult in view of the different historical traditions and institutional peculiarities of the various

\footnotetext{
${ }^{16}$ When specifying measures to encourage co-operation in the area of employment policy, the
} Amsterdam Treaty speaks of "initiatives aiming at developing exchanges of information and best 
member states, and of the significance attached to labour-market institutions in the national political debate (Calmfors et al, 1997; Pissarides, 1997; Sibert \& Sutherland, 1997; Calmfors, 1998). Labour-market institutions would seem to belong to the core of national decision-making that is least likely in practice to be transferred to the EU level.

\subsection{Labour-market reform, exchange rates and inflation}

A common argument in policy circles (and a gut reaction among many economists) is that participation in the EMU must clearly strengthen the incentive for labour-market reform to reduce structural unemployment. The reasoning has almost obtained the character of a folk theorem in the EMU discussion. It can be seen as a version of Mrs Thatcher's There-Is-No-Alternative (TINA) strategy: if demand policy is immobilised, the policy maker has little option but to undertake reform (Bean, 1998). The presumption is that the painful adjustments needed to reduce unemployment will not be accepted until the escape route of depreciating the own currency is definitely closed.

The problem with this argument is that it explains why the EMU could lead to more money-wage flexibility in order to reduce cyclical variability (as discussed in section 3), but not why the political incentives to reduce equilibrium unemployment would increase. If one believes in the long-run neutrality of money, there is no reason why easy monetary policy and exchange-rate depreciations should reduce equilibrium unemployment. Nor is there any reason to expect systematic monetary policy to reduce the actual rate of unemployment below the equilibrium one - which might possibly also reduce the equilibrium rate over time via hysteresis (persistence) mechanisms - because a decision to pursue such a policy would get built into wage setters' expectations if these are rational. So why should giving up an instrument that does not work strengthen the incentives for other instruments, viz. labour-market reform, that do work? The TINA argument would seem to presuppose either that the same reforms that make money wages more flexible also reduce real-wage levels and/or relative-wage distortions (for which we do not have any theoretical or

practices, providing comparative analysis and advice as well as promoting innovative approaches and evaluating experiences" (article 129). 
empirical support), or that economic policy is systematically based on misperceptions (which does not square with the rational-expectations paradigm). ${ }^{17}$

However, it is possible to reverse the TINA argument in a logically consistent way. This has been done by Sibert \& Sutherland (1997) and Calmfors (1998). ${ }^{18}$ In their models policy makers, who dislike both unemployment and inflation as well as labour-market reform (because of the political cost), decide both on the amount of reform and on monetary policy. If monetary policy outside the EMU is discretionary, there will, as in the Barro-Gordon (1983) model, be an inflation bias. The bias will be larger the higher is equilibrium unemployment, because the temptation to reduce unemployment through unanticipated inflation is then greater. Policy makers will take this into account when deciding on labour-market reform. Hence, there is an extra incentive to reduce equilibrium unemployment for a country not participating in the EMU: labour-market reform does not only increase social welfare directly by reducing (expected) unemployment, it also does so indirectly because lower equilibrium unemployment reduces the inflation bias. ${ }^{19}$

Inside the EMU, this extra incentive for reform will be much weaker. This must, of course, be the case if the ECB is less inflation-prone than national central banks. Indeed, with a zero inflation bias, there will be no such extra incentive at all. But the argument goes through also if the ECB suffers from the same (or a larger) inflation bias than the national central banks. The reason is that the ECB's monetary policy will be based on aggregate developments in the EMU: because labour-market reform in an individual country has only a small effect on aggregate equilibrium unemployment in the monetary union, it will also reduce aggregate inflation to a very small extent. So the combination of national labour-market policy and a common monetary policy

\footnotetext{
${ }^{17}$ The strongest support for the TINA argument is probably that so many policy makers seem to believe in it. I owe this observation to Torsten Persson. But strangely enough, the same policy makers usually endorse the view in other contexts that monetary policy cannot reduce unemployment in the long run in the absence of structural labour-market reform.

${ }^{18}$ See also Grüner \& Hefeker (1998) and Hefeker (1998).

${ }^{19}$ One should note the difference between the TINA argument and the inflation-bias argument. Even if policy makers realise that unemployment cannot be lowered below the equilibrium rate through inflation, they will still choose to inflate in the Barro-Gordon model. The reason is that this is the only time-consistent policy, i.e., the only optimal policy once wage contracts based on rational expectations have been concluded. But it will never be rational for policy-makers to abstain from reform because they have access to monetary policy in this framework.
} 
means that each member country in the EMU internalises only a fraction of the benefit of reform. On this account, the incentive to undertake labour-market reform is weakened by EMU membership. ${ }^{20}$ It is weakened more for small than for big EU countries, because the former internalise only a negligible fraction of the benefit of reform.

How should one judge this inflation-bias argument? Bean (1998) has criticised it on the ground that there is little reason to expect national monetary policy outside the EMU to suffer from an inflation bias, once it has been delegated to an independent central bank. There are also well-known theoretical models, in which the inflation bias can be eliminated through proper incentive schemes without interfering with optimal stabilisation efforts (Walsh, 1995; Persson \& Tabellini, 1993; Svensson, 1997). And one could claim that the recent reduction in inflation rates within the EU bears this argument out.

However, a counterargument is that it ought to be theoretically impossible to eliminate the inflation bias of monetary policy completely through the combination of delegation and proper incentive schemes, as long as the possibility of discretionary stabilisation policy is retained. There is an inherent contradiction in assuming that a government, which has delegated monetary policy because it cannot handle its own incentive problems, would enforce a contract with the central bank that leads to the optimal policy it cannot deliver itself (McCallum, 1995; Jensen, 1997). With this view, the recent reduction of inflation rates in the EU countries - and possibly also the move towards more independent central banks - might be interpreted as a temporary phenomenon associated with the desire to qualify (or at least keep the possibilities) for EMU membership open (Ozkan et al., 1997).

\subsection{The interaction between labour-market reform and monetary policy}

\footnotetext{
${ }^{20}$ Cukierman \& Lippi (1997) have analysed how trade-union behaviour could lead to similar results. In their model, centralised trade unions in an individual country that are concerned with inflation (in addition to real wages and employment) have an incentive to restrain real wages, because this reduces equilibrium unemployment and thus the inflation bias of the central bank. Inside the EMU, even a centralised national trade union will be too small relative to the ECB for this effect to be important.
} 
There is another and stronger argument for why labour-market reform may be easier outside than inside the EMU. It builds on the assumption that reform and demand policy are economic as well as political complements (Bean, 1994, 1998; Alogoskoufis et al., 1995; Lindbeck, 1996; Calmfors et al., 1997; Calmfors, 1998). The idea is that the full benefits of reform in terms of lower unemployment may take a very long time to materialise in a situation of low demand. A case in point is the labour market reforms in the UK under Mrs Thatcher (Minford, 1994). The long time lag between impopular measures and results could tilt the balance against reform for governments that have to prove their competence to voters before the next election.

The argument is illustrated in Figure 9, where the vertical line is a wage-setting schedule (showing the equilibrium rate of employment that wage setters seek to achieve) and the downward-sloping line is a labour-demand schedule. Labour-market reform shifts the wage-setting schedule to the right. If money wages and prices were perfectly flexible, there would be an immediate real-wage reduction and the economy would move directly from A to B. The counterpart in goods markets would be a real depreciation of the currency (a fall in the relative price of domestic versus foreign goods), so that the increased output associated with higher employment can be sold.

Now, assume that the money-wage level is rigid downwards (or that there is a lower floor for money-wage increases). With high inflation, this would not impede the realwage adjustment, because money-wage growth needs only to fall below inflation. But with low inflation, this cannot happen. Then, the nominal rigidity is a binding constraint on how large real-wage reduction that can be achieved in the short term. The economy may move only to $\mathrm{C}$ instead of to $\mathrm{B}$, so that there is only a small fall in unemployment. Say's law is prevented from operating. To get to B in the short term, an accommodating monetary policy is needed, so that prices rise at such a rate that the potential real-wage cut can be achieved without interfering with the money-wage restriction.

As discussed by Bean (1998), there are also several reasons why aggregate-demand developments could counteract the positive employment effects of labour-market reform in the short run. Real interest rates may rise, if the real-wage adjustment is 
associated with price deflation. There may be increased uncertainty in the economy in connection with the reforms, leading to more of precautionary savings. Consumption may fall because income is redistributed away from wage earners to capital owners with lower propensities to consume, and investment may not pick up immediately (for example, because there is an option value of waiting due to the uncertainty of how large real-wage adjustments and thus increases in the return to capital that will ultimately occur).

This reasoning has direct implications for the possibilities to implement labour-market reform inside and outside the EMU. With low inflation in the EMU, it is conceivable that national labour-market reform would fail to produce a significant reduction of real wages and unemployment in the short run, because the monetary policy of the ECB will not respond to events in an individual country. But a country outside the EMU has the option of co-ordinating reform and monetary policy to speed up the response of actual to equilibrium unemployment. This could make reform more appealing and facilitate political agreement. This may make reform more likely outside than inside the EMU. ${ }^{21}$

It might be thought that the idea of co-ordinating labour-market reform and monetary policy is far-fetched when the former is decided by the political system and the latter by an independent central bank. One might also worry about the inflation consequences of an accommodating monetary policy. But in an inflation-target regime, such a policy is the proper response to the type of supply shock that a reduction of equilibrium unemployment represents (Calmfors et al., 1997; Calmfors, 1998). If reform leads to some reduction in money-wage growth, there will be a fall in the rate of price increase for domestic goods. Hence, there is a downward deviation from the inflation target for the CPI. With an inflation target, this motivates a more expansive monetary policy to induce a currency depreciation. In contrast, the outcome

\footnotetext{
${ }^{21}$ Note that this argument makes it necessary to specify more clearly which the political costs of reform are. If the benefit of an accommodating monetary policy is perceived to be faster real-wage adjustment, then the political cost cannot reasonably be associated with the fall in insiders' real wages. The cost could instead be associated with factors like less insurance against unemployment (in the case of less generous unemployment compensation), more exposure to unemployment (in the case of less employment protection) or a change in the general balance of power between employees and employers (in the case of restrictions on the right to strike etc.). Another candidate is the pure political negotiation
} 
of reform in an individual country participating in the EMU must be a temporary reduction in the rate of consumer price inflation (or temporary price deflation), because there will be no monetary-policy response to the fall in the rate of price increase for domestic goods.

At least two qualifications should be made in this context. First, the sum of a low rate of inflation (say 2 per cent) and productivity growth (say 2 per cent as well) gives some room also in the EMU for reductions of money-wage growth before downward rigidity begins to bite. This will be the case especially if reform is carried out in a gradual manner. But it is not at all clear that this is possible. Most discussions of labour-market reform stress the need for a comprehensive reform programme to compensate losers from individual measures and to maximise the chances of success in a situation where there is large uncertainty on the effects (e.g., Alogoskoufis et al., 1995; OECD, 1994; Lindbeck, 1996; Calmfors et al., 1997; Elmeskov et al., 1998; and Orszag \& Snower, 1998). And "windows of opportunity" for labour-market reform may occur very rarely, because the timing needs to be right with respect to both economic and political factors (Calmfors et al., 1998; Bean, 1998; Elmeskov et al., 1998).

The second qualification concerns the genuine uncertainty regarding the quantitative effect of labour-market reform on equilibrium unemployment. Bean (1996) has analysed how uncertainty about equilibrium unemployment may motivate a central bank to aim for higher unemployment than the equilibrium one: with a non-linear (convex) Phillips curve, periods of excess demand must be compensated by periods of even larger excess supply, if the inflation target is to be met on average. So increased uncertainty in connection with labour-market reform is an argument to aim for a larger average discrepancy between actual and equilibrium unemployment, i.e., for less vigorous monetary policy expansion in connection with the reform than would be the case if the effects were known with certainty. But there is also an argument to the opposite: with uncertainty about the equilibrium rate of unemployment, there is a case for (cautious) experimenting in order to find out what it is (Wieland, 1998). 


\subsection{Precautionary motives for labour-market reform in the EMU}

Provided that monetary policy does not suffer from an inflation bias, there exists also a clear-cut argument for why the incentive for reform could be stronger inside than outside the EMU. The argument builds on the assumption that what policy makers are primarily interested in with respect to unemployment is to avoid very bad outcomes, and that they attach an extra value to reducing the risks of them. The hypothesis is that variations in unemployment are regarded as more serious, the higher the average (equilibrium) rate of unemployment around which these variations occur. Such a value judgement was expressed by the Swedish Government Commission on the EMU (Calmfors, et al., 1997).

With this assumption, the reasoning is straightforward (Calmfors, 1998). If membership in the EMU leads to larger variations in employment, because monetary policy no longer stabilises country-specific shocks, there is a precautionary motive for more reform inside than outside the EMU. The reasoning is analogous to the analysis of precautionary savings (Leland, 1968). According to that, increased uncertainty leads households to save more, because higher expected future consumption is a way of reducing the utility cost of variations in consumption. In a similar way, policy makers may choose more labour-market reform to lower equilibrium unemployment when macroeconomic instability increases, so as to reduce the utility cost of employment variations.

The reasoning is illustrated in Figure 10, where the marginal disutility that the government attaches to unemployment has been drawn. The crucial assumption is that marginal disutility is convex, i.e., that it increases more rapidly, the larger the deviation of unemployment from the government's unemployment target $\hat{u}$. (Technically, this requires the third derivative of the government's preference (disutility) function to be positive, just as the third derivative of utility with respect to consumption must be positive in the theory of precautionary savings). This is a way of capturing a very strong dislike of high unemployment. ${ }^{22}$

\footnotetext{
${ }^{22}$ Obviously, a conventional quadratic loss function will not do to generate the marginal disutility function in Figure 10. A simple government disutility function with the desired properties would be
} 
currency will increase competition and economic integration. Product demand will become more sensitive to price differentials between different countries and firms' location decisions more responsive to relative labour costs (Bean, 1998; Gros \& Thygesen, 1998). This will increase pressure on governments to implement labourmarket reform that lowers real labour costs. Similarly, increased product and labour demand elasticities create an incentive for wage setters to opt for lower real wages at given reform levels.

The above arguments are qualitatively correct. But it remains unclear how quantitiatively important a common currency is to increase competition and integration relative to the development that is already occurring also without the EMU.

In sum, my discussion does not lead to a clear-cut conclusion on the likely net effect of monetary union on structural unemployment. Standard arguments about the link between monetary policy and labour-market reform appear logically flawed. The logically consistent arguments go in different directions and are all subject to various objections. So there is no clear presumption how the EMU is likely to affect structural unemployment. Other determinants of the political feasibility of labour-market reform, such as the comprehensiveness of a reform package, the timing of measures, the determinedness of a government and its general political support are likely to be much more important.

My conclusion would seem to square well with the very diverse country experiences. On one hand, the US is an example of a currency union with labour-market institutions that are conducive to low equilibrium unemployment. On the other hand, the strong ERM linkages of countries like France and Belgium do not seem to have helped promote comprehensive labour-market reform in these countries, although the Netherlands, and possibly also Denmark, could be seen as examples where this may to some extent have occurred (Elmeskov et al., 1998). The most far-reaching labourmarket reform in recent years have been made in the UK and New Zealand without pressures from external currency arrangements, but within strict low-inflation regimes (OECD, 1997; Elmeskov et al., 1998). 
Assume that there is a given equilibrium (average) rate of unemployment, $u^{*}$, around which cyclical fluctuations occur. Outside the EMU, when domestic monetary policy can be used to stabilise asymmetric shocks, actual unemployment is either $u_{1}$ or $u_{2}$ depending on whether there are positive or negative shocks (both occurring with probability 0.5$).{ }^{23}$ Hence the expected marginal disutility of equilibrium (average) unemployment $u^{*}$ is $E_{A}$. With membership in the EMU, asymmetric shocks can no longer be stabilised and unemployment variations around the given equilibrium level are therefore larger: unemployment becomes either $u_{3}$ or $u_{4}$ (again both with probability 0.5 ). Then the expected marginal disutility of equilibrium unemployment $u^{*}$ increases to $E_{B}$. A larger expected marginal disutility of equilibrium unemployment means also a larger expected marginal gain from reform that reduces equilibrium unemployment. This larger gain should be set against the political cost of reform. It follows that the incentive for reform becomes stronger inside the EMU than outside. $^{24}$

\subsection{The net effect of EMU on equilibrium unemployment}

Most other arguments regarding the effect of the EMU on equilibrium unemployment build on the hypothesis that the increased transparency associated with a common

$L=\left[(\pi-\hat{\pi})^{4}+\lambda(u-\hat{u})^{4}+\gamma s\right] / 4$, where $\pi=$ inflation, $\hat{\pi}=$ the inflation goal of the government, $u=$ unemployment, $\hat{u}=$ the unemplyment goal, and $s=$ the amount of labour-market reform (see Calmfors, 1998).

${ }^{23}$ Assume that unemployment is $u=u^{*}-\beta\left(\pi-\pi^{e}\right)+\varepsilon$, where $u^{*}=$ equilibrium unemployment, $\pi^{e}=$ expected inflation, and $\varepsilon=$ an asymmetric random shock (to simplify I here neglect symmetric shocks). If the central bank has the same preference function as the government (see footnote 22) except that its unemployment goal is equal to the equilibrium rate of unemployment, it will choose inflation so that $\pi=\hat{\pi}+k \varepsilon$, where $k=\sqrt[3]{\beta \lambda} /\left(1+\sqrt[3]{\beta^{4} \lambda}\right)$, so that there is partial stabilisation of shocks.

${ }^{24}$ The above argument is clear cut because of the assumption of no inflation bias. The analysis becomes more complex with such a bias, if the marginal disutility of inflation is also assumed to be convex. The reason is that lower equilibrium unemployment reduces the inflation bias outside the EMU (see footnote 22). Hence, in this case there is an extra incentive outside the EMU for national labour-market reform to reduce the (expected) rate of inflation and thus also the utility costs of variations in inflation. Note also that if reform could be co-ordinated among the EMU member states, then the precautionary argument for more reform inside than outside the EMU to reduce the utility cost of employment variations would still hold. (But there would also be an effect working in the opposite direction, if the ECB and national central banks suffer from an inflation bias of the same magnitude. The reason is that monetary policy in the EMU will entail smaller fluctuations in inflation to stabilise shocks than national monetary policy outside the EMU, because the aggregate shocks in the EMU area will be smaller than the national ones to the extent that country-specific shocks cancel out.) 
currency will increase competition and economic integration. Product demand will become more sensitive to price differentials between different countries and firms' location decisions more responsive to relative labour costs (Bean, 1998; Gros \& Thygesen, 1998). This will increase pressure on governments to implement labourmarket reform that lowers real labour costs. Similarly, increased product and labour demand elasticities create an incentive for wage setters to opt for lower real wages at given reform levels.

The above arguments are qualitatively correct. But it remains unclear how quantitiatively important a common currency is to increase competition and integration relative to the development that is already occurring also without the EMU.

In sum, my discussion does not lead to a clear-cut conclusion on the likely net effect of monetary union on structural unemployment. Standard arguments about the link between monetary policy and labour-market reform appear logically flawed. The logically consistent arguments go in different directions and are all subject to various objections. So there is no clear presumption how the EMU is likely to affect structural unemployment. Other determinants of the political feasibility of labour-market reform, such as the comprehensiveness of a reform package, the timing of measures, the determinedness of a government and its general political support are likely to be much more important.

My conclusion would seem to square well with the very diverse country experiences. On one hand, the US is an example of a currency union with labour-market institutions that are conducive to low equilibrium unemployment. On the other hand, the strong ERM linkages of countries like France and Belgium do not seem to have helped promote comprehensive labour-market reform in these countries, although the Netherlands, and possibly also Denmark, could be seen as examples where this may to some extent have occurred (Elmeskov et al., 1998). The most far-reaching labourmarket reform in recent years have been made in the UK and New Zealand without pressures from external currency arrangements, but within strict low-inflation regimes (OECD, 1997; Elmeskov et al., 1998). 


\section{Conclusions}

My discussion leads to the following five conclusions.

(1) Although an inflation-target regime, as recently adopted by the UK and Sweden, imposes constraints on the monetary policy of an EU country not participating in the EMU (an out), it still leaves considerable scope for stabilisation policy in the event of country-specific demand shocks, provided that there is some flexibility of nominal prices and wages.

(2) It appears unlikely that external pressures from the EMU countries (the ins) would act as a severe constraint on the monetary policy of the outs in the case of major macroeconomic shocks.

(3) A possible substitute for exchange-rate changes inside the EMU, which has not received enough attention, is to use fiscal policy for expenditure-switching purposes. The real exchange rate can be changed through variations in payroll taxes. This will not affect the fiscal balance - and thus not conflict with the EMU fiscal rules - as long as compensating variations are made in other taxes or in government expenditures. But because of the political inertia associated with fiscal-policy decisions, such internal exchange-rate changes are likely only to be an imperfect substitute for an independent monetary policy.

(4) The unsatisfactory state of knowledge regarding the causes of money-wage rigidity makes it difficult to predict to which extent EMU membership will contribute to more money wage flexibility. Both theoretical reasoning and empirical experiences would seem to warn against too great optimism. It is even possible that the reductions in inflation rates that have recently occurred will make money wages more rigid than in the past.

(5) There is general uncertainty on how the EMU may affect the political incentives for labour-market reform to reduce structural unemployment. The folk theorem in policy circles that elimination of the exchange-rate option is bound to strengthen 
the incentive for more painful adjustments to solve the unemployment problem is not vindicated by economic analysis. Instead, one can point to factors that work in different directions. It is quite likely that the EMU will not have any major impact on the extent of labour-market reform and structural unemployment. 


\section{References}

Agell, J. and P. Lundborg (1995), 'Theories of Pay and Unemployment: Survey Evidence from Swedish Manufacturing Firms', Scandinavian Journal of Economics, 97.

Akerlof, G. A. (1982), 'Labor Contracts as Partial Gift Exchange', Quarterly Journal of Economics, 97.

Akerlof, G. A. and J. Yellen (1990), 'Fairness and Unemployment' American Economic Review, papers and proceedings, 78.

Akerlof, G. Dickens, W. and G. Perry (1996), 'The Macroeconomics of Low Inflation', Brookings Papers on Economic Activity, 1.

Alogoskoufis, G., Bean, C. R., Bertola, G., Cohen, D., Dolado, J. and G. Saint-Paul (1995), Unemployment: Choices for Europe, Monitoring European Integration Series, 5, CEPR, London.

Andersen, T. (1997), 'Fiscal Policy in the EMU and Outside', Swedish Economic Policy Review, 4.

Avtal om principerna för hur ändringarna $i$ arbetspensionsförsäkrings- och arbetslöshetsskyddsavgifterna skall utjämnas vid konjunkturväxlingar (1997), Helsinki, 18 November.

Ball, L. (1987), 'Externalities from Contract Length', American Economic Review, 77.

Ball, L. (1994), 'What Determines the Sacrifice Ratio?', in Mankiw, N. G., ed., Monetary Policy, NBER and University of Chicago.

Ball, L. Mankiw, N. G. and D. Romer (1988), 'The New Keynesian Economics and the Output-Inflation Trade-off', Brookings Papers on Economic Activity, 1.

Ball, L. and D. Romer (1991), 'Sticky Prices As Coordination Failure', American Economic Review, 81.

Barro, R. and D. B. Gordon (1983), 'A Positive Theory of Monetary Policy in a Natural Rate Model', Journal of Political Economy, 91.

Bayoumi, T. and B. Eichengreen (1993), 'Shocking Aspects of European Monetary Integration', in Torres, F. and F. Giavazzi, ed., Adjustment and Growth in the European Monetary Union, Cambridge University Press, Oxford, New York and Melbourne.

Bean, C. (1994) 'The Role of Demand Management Policies in Reducing Unemployment', Reducing Unemployment: Current Issues and Policy Options, A Symposium Sponsored by the Federal Reserve Bank of Kansas City, Jackson Hole, Wyoming, 25-27 August.

Bean, C. R. (1996), 'The Convex Philips Curve and Macroeconomic Policymaking under Uncertainty', mimeo, LSE.

Bean, C. R. (1998), 'The Interaction of Aggregate-Demand Policies and LabourMarket Reform', forthcoming in Swedish Economic Policy Review. 
Bewley, T. F. (1995), 'A Depressed Labour Market Index as Explained by Participants', American Economic Review, papers and proceedings, 85.

Bewley, T. F. (1998), 'Why Not Cut Pay?', European Economic Review, 42.

Blanchard, O. J. (1986), 'The Wage Price Spiral', Quarterly Journal of Economics, 101.

Blinder, A. and D. H. Choi (1990), 'A Shred of Evidence on Theories of Wage Stickiness', Quarterly Journal of Economics, 105.

Boldt, P. J. (1998), 'Finnish Social Partner Agreement on Counter-Cyclical EMU Buffers', mimeo, Finnish Confederation of Labour.

Bruno, M. and J. Sachs (1985), The Economics of Worldwide Stagflation, Oxford, Basil Blackwell.

Buti, M., Franco, D. and H. Ongena (1998), 'Fiscal Discipline and Flexibility in EMU', this volume.

Calmfors, L. (1982), 'Employment Policies, Wage Formation and Trade Union Behaviour in a Small Open Economy', Scandinavian Journal of Economics, 1982:2. Reprinted in Bénassy, J-P, ed., Macroeconomics and Imperfect Competition, Edward Elgar, 1995.

Calmfors, L. (1993), 'Lessons from the Swedish Macroeconomic Experience', European Journal of Political Economy, 9.

Calmfors, L. (1996), 'Nationalekonomernas roll under det senaste decenniet - vilka är lärdomarna?', in Jonung, L., ed., Ekonomernas roll i debatten - gör de någon nytta? IVA och Ekerlids Förlag, 1996.

Calmfors, L. (1998), 'Unemployment, Labour-Market Reform and Monetary Union', IIES Seminar Paper No. 639.

Calmfors, L. and H. Horn (1986), 'Employment Policies and Centralized Wage Setting', Economica, 53.

Calmfors, L., Flam, H., Gottfries, N., Jerneck, M., Lindahl, R., Haaland Matlary, J., Nordh Berntsson, C., Rabinowicz, E. and A. Vredin (1997), EMU - A Swedish Perspective, Kluwer Academic Publishers.

Calmfors, L., Manning, A., and G. Saint-Paul (1998), 'A Balanced Approach to Employment Policy in Europe', Treasury Working Paper No. 70, London.

Campbell, C. M. III and K. S. Kamlani (1997), 'The Reasons for Wage Rigidity: Evidence from a Survey of Firms', Quarterly Journal of Economics, 112.

Canzoneri, M., Valles, J. and J. Vinals (1996), 'Do Exchange Rates Move to Address International Macroeconomic Imbalances?', CEPR Discussion Paper No. 1498, October.

Card, D. and D. Hyslop (1996), "Does Inflation 'Grease the Wheels or the Labour Markets"'? in Romer, C. D. and D. H. Romer, Reducing Inflation. Motivation and Strategy, The University Press of Chicago, Chicago and London.

Clarida, R. and J. Gali (1994), 'Sources of real exchange rate fluctuations: how important are nominal shocks?', CEPR Discussion Paper No. 951. 
Cukierman, A. and F. Lippi (1997), 'Central Bank Independence, Centralization of Wage Bargaining, Inflation and Unemployment - Theory and Evidence', mimeo, Tilburg University and Banca d'Italia.

Dornbusch, R., Favero, C. and F. Giavazzi (1998), 'Immediate Challenges for the European Central Bank', Economic Policy, 26.

Egebo, T. and A. S. Englander (1992), 'Institutional Commitments and Policy Credibility: A Critical Survey and Empirical Evidence from the ERM', OECD Economic Studies, 18.

Eichengreen, B. and C. Wyplosz (1998), 'The Stability Pact: More Than a Minor Nuisance?', Economic Policy, 26.

Ekonomiska utsikter - våren (1998), LO, Stockholm.

Elmeskov, J., Martin, J. P. and S. Scarpetta (1998), 'Key Lessons for Labour Market Reforms: Evidence from OECD Countries' Experiences', forthcoming in Swedish Economic Policy Review.

Erkel-Rousse, H. and J. Mélitz (1995), 'New Empirical Evidence on the Costs of European Monetary Union’, CEPR Discussion Paper No. 1169, May.

Fatás, A. (1997) 'EMU: Countries or Regions? Lessons from the EMS Experience', CEPR Discussion Paper No. 1558.

Forslund, A. (1995), 'Unemployment - Is Sweden Still Different?', Swedish Economic Policy Review, 2.

Freeman, R. B. (1998), 'Reforming Wage Formation: Toward a New Swedish System?', mimeo, Harvard University and NBER.

Fregert, K. (1994), Wage Contracts, Policy Regimes and Business Cycles - a Contractual History of Sweden 1908-1990, Lund Economic Studies, Studentlitteratur, Lund.

Friedman, M. (1953), 'The Case for Flexible Exchange Rates', Essays in Positive Economics, University of Chicago, Chicago.

Gottfries, N. (1992), 'Insider, Outsiders and Nominal Wage Contracts', Journal of Political Economy, 100.

Gros, D. and N. Thygesen (1998), European Monetary Integration - from the European Monetary System to Economic and Monetary Union, Addison Wesley Longman, London and New York.

Grubb, D., Jackman, R. and R. Layard (1983), 'Wage Rigidity and Unemployment in OECD Countries', European Economic Review, 21.

Grüner, H. P. and C. Hefeker (1998), 'How will EMU Affect Inflation and Unemployment in Europe?', mimeo, University of Bonn and University of Basel.

Hassler, J. (1997), 'International Covariation in Manufacturing 1975-1995', Swedish Economic Policy Review, 4.

Hefeker, C. (1998), 'Labor Market Rigidities, Unions and Monetary Union', WWZDiscussion Paper, No. 9801, Wirtschaftswissenschaftliches Zentrum, University of Basel. 
Holden, S. (1994), 'Wage Bargaining and Nominal Rigidities', European Economic Review, 38.

Holden, S. (1997), 'Wage Bargaining, Holdout, and Inflation', Oxford Economic Papers, 49.

Holden, S. and R. Nymoen (1998), 'Measuring Structural Unemployment: Is there a Rough and Ready Answer?', mimeo, Department of Economics, University of Oslo.

Jansson, P. (1997), 'How Large is the Risk of Assymetric Shocks for Sweden', Swedish Economic Policy Review, 4.

Jensen, H. (1997), 'Credibility of Optimal Monetary Delegation', American Economic Review, 87.

Johansson, K. (1998), 'The Econometric Model KOSMOS', mimeo, National Institute of Economic Research, Stockholm.

Johnson, H. (1970), 'The Case for Flexible Exchange Rates', 1969, in G. Halm, ed., Approaches to Greater Flexibility of Exchange Rates, the Bürgenstock Papers, Princeton University Press, Princeton.

Keynes, J. M. (1936), The General Theory of Employment, Interest, and Money. Macmillan, London.

Layard, R., Nickell S. and R. Jackman, (1991), Unemployment, Oxford University Press, Oxford.

Layard, R. and S. Nickell (1997), 'Labour Market Institutions and Economic Performance', Discussion Paper Series No. 23, Centre for Economic Performance.

Leland, H. (1968), 'Saving and Uncertainty: The Precautionary Demand for Saving', Quarterly Journal of Economics, 82.

Lindbeck, A. (1996), 'The West European Employment Problem', Weltwirtschaftliches Archiv, December.

McCallum, B. T. (1995), 'Two Fallacies Concerning Central-Bank Independence', American Economic Review, papers and proceedings, 85.

Mélitz, J. (1997), 'The Evidence about the Costs and Benefits of EMU', Swedish Economic Policy Review, 4.

Minford, P. (1994), 'Deregulation and Unemployment - The UK Experience', Swedish Economic Policy Review, 1.

Nickell, S. (1997), 'Unemployment and Labor Market Rigidities: Europe versus North America', Journal of Economic Perspectives, 11.

Obstfeld, M. and G. Peri (1998), 'Regional Non-Adjustment and Fiscal Policy', Economic Policy, 26.

OECD (1994), The OECD Jobs Study, OECD, Paris.

OECD (1997), Implementing the OECD Jobs Strategy: Lessons from Member Countries' Experience, OECD, Paris. 
Orszag, M. and D. J. Snower (1998), 'The Anatomy of Policy Complementaries', forthcoming in Swedish Economic Policy Review.

Ozkan, F. G., Sibert, A. and A. Sutherland (1997), 'Monetary Union, Entry Conditions and Economic Reform', CEPR Discussion Paper No. 1720.

Personalfonder samt andra frivilliga EMU-buffertar på företagsnivå (1997), Helsinki, $16 / 11$.

Persson, M. (1996), 'Märklig EMU-analys', Dagens Nyheter, 2 April.

Persson, T. and G. Tabellini (1993), 'Designing Institutions for Monetary Stability', Carnegie-Rochester Conference Series on Public Policy, 29.

Pissarides, C. (1997), 'The Need for Labour Market Flexibility in European Economic and Monetary Union', Swedish Economic Policy Review, 4.

Ramaswamy, R. and T. Sloek (1997), 'The Real Effects of Monetary Policy in the European Union: What are the Differences?', IMF Working Paper, December.

Resolution of the European Council on the Establishment of an Exchange-Rate Mechanism in the Third Stage of Economic and Monetary Union (1997), Amsterdam, 16 June.

Resolution of the Council of the European Union on the 1998 Employment Guidelines (1997), Luxembourg, 15 December.

Rödseth, A. and R. Nymoen (1998), 'Nordic Wage Formation and Unemployment Seven Years Later', mimeo, Department of Economics, University of Oslo.

Saint-Paul, G. (1993), 'On the Political Economy of Labor Market Flexibility', NBER Macroeconomics Annual.

Saint-Paul, G. (1995), 'A Framework for Analysing the Political Support for Active Labour Market Policy’, CEPR Discussion Paper No. 1205.

Saint-Paul, G. (1996), 'Exploring the Political Economy of Labour Market Institutions', Economic Policy, 23.

Saint-Paul, G. (1998), 'The Political Consequences of Unemployment', forthcoming in Swedish Economic Policy Review.

Sibert, A. C. and A. Sutherland (1997), 'Monetary Regimes and Labour Market Reform', CEPR Discussion Paper No. 1731.

Solow, R. M. (1979), 'Another Possible Source of Wage Stickiness', Journal of Macroeconomics, 1.

Stockman, A. (1988), 'Real Exchange Rate Variability under Pegged and Floating Nominal Exchange Rate Systems: An Equilibrium Theory', Carnegie-Rochester Conference Series on Public Policy, 29.

Ställningstagande till den europeiska ekonomiska och monetära unionens inverkan på verksamhetsprinciperna på arbetsmarknaden (1997), Helsinki.

Svensson, L. E. O. (1997), “Optimal inflation Targets, 'Conservative' Central Banks, and Linear Inflation Contracts", American Economic Review, 85.

Svensson, L. E. O. (1998), ‘Open-Economy Inflation Targeting', mimeo, Institute for International Economic Studies, Stockholm. 
Söderström, H. and S. Viotti (1978), 'Money Wage Disturbances and the Endogeneity of the Public Sector in an Open Economy', in A. Lindbeck, ed., Inflation and Employment in Open Economies, North-Holland, Amsterdam.

Taylor, J. B. (1980), 'Aggregate Dynamics and Staggered Contracts', Journal of Political Economy, 88.

Thomas, A. (1997), 'Is the Exchange Rate a Shock Absorber? The Case of Sweden', IMF Working Paper, December.

Thygesen, N. (1995), 'The Prospects for EMU by 1999 - and Reflections on Arrangements for the Outsiders', EPRU Working Paper No. 1995-17, Köpenhamns handelshögskola.

Thygesen, N. (1998), 'Fiscal Institutions in EMU and the Stability Pact', in A. Hughes-Halleet, ed., Fiscal Aspects of European Monetary Integration, Cambridge University Press, Cambridge, forthcoming.

Wieland, V. (1998), Monetary Policy and Uncertainty about the Natural Employment Rate, Working Paper, Federal Reserve Board, Washington.

Walsh, C. (1995), 'Optimal Contracts for Independent Central Bankers', American Economic Review, 85.

Wright, R. (1986), 'The Redistributive Roles of Unemployment Insurance and the Dynamics of Voting', Journal of Public Economics, 31. 
The response of the economy to a recessionary shock under different monetary policies

Figure 1. Nominal exchange rate (deviation from baseline)

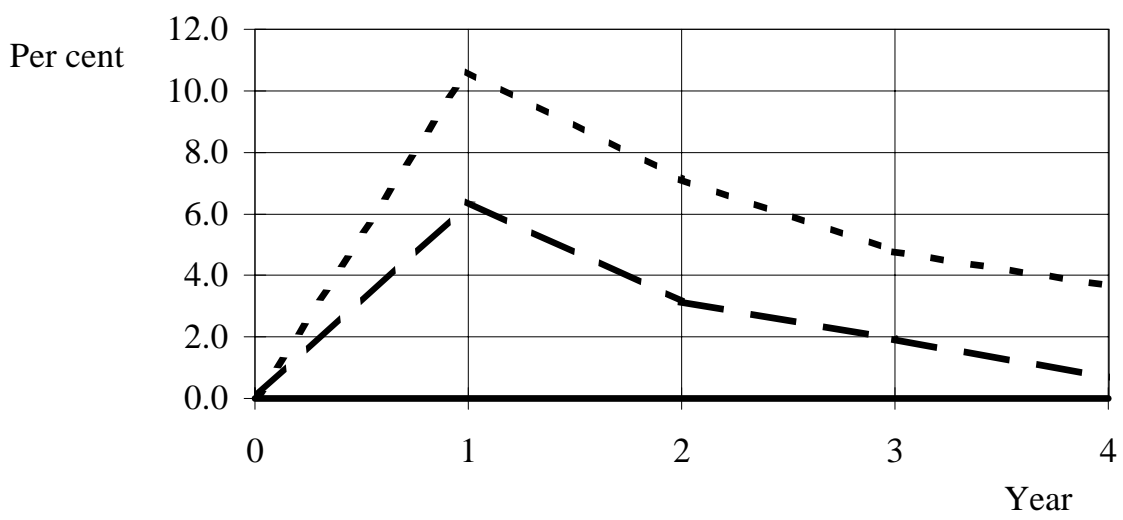

Figure 3. Exports (devation from baseline)

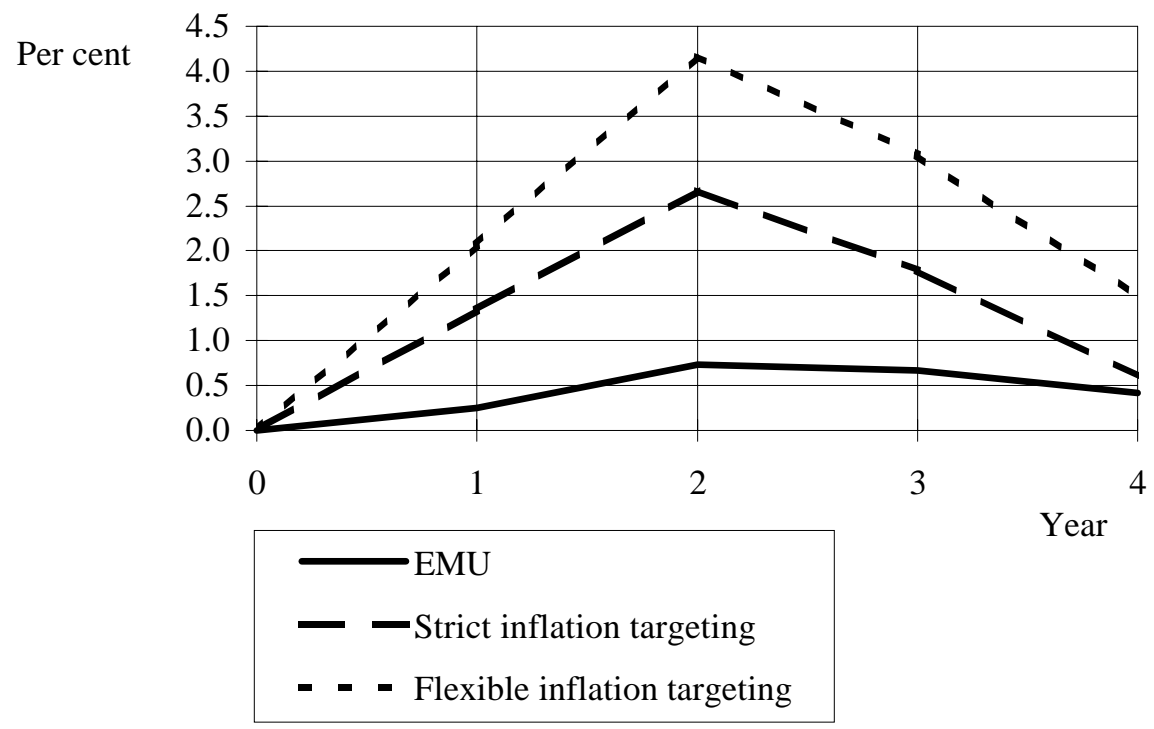

Figure 2. Relative export price (deviation from baseline)

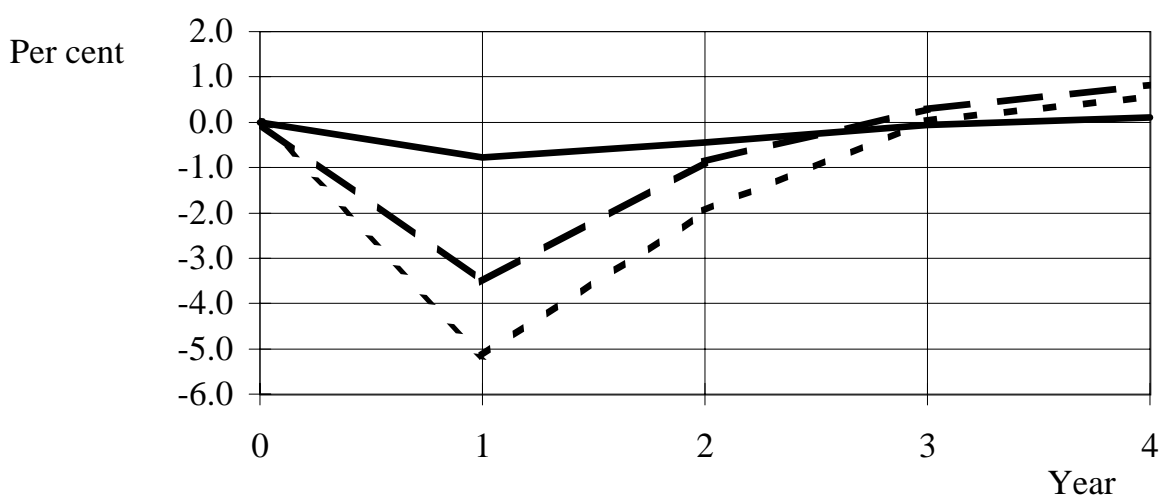

Figure 4. Real short-term interest rate (devation from baseline)

Per cent

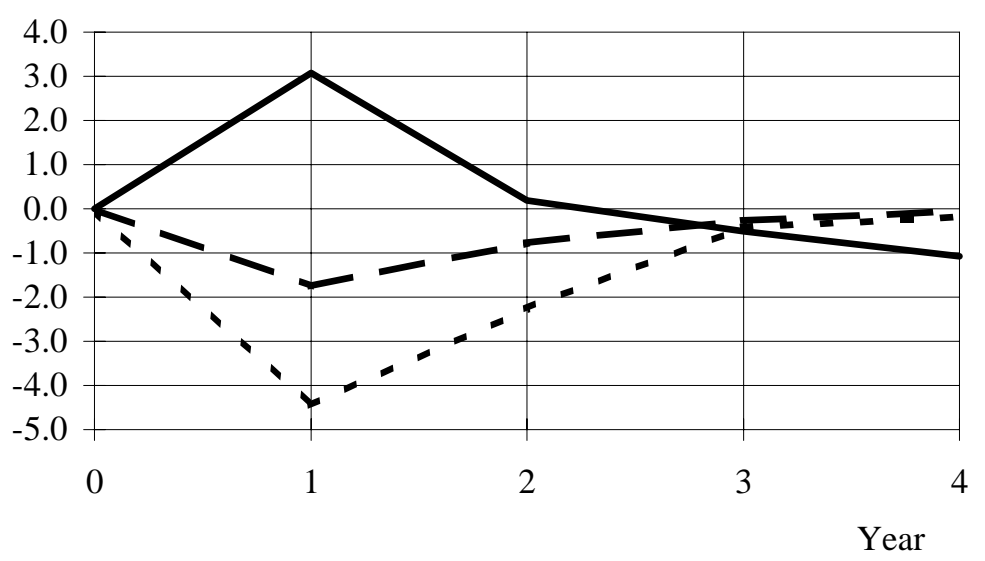


The response of the economy to a recessionary shock under different monetary policies

Figure 5. Domestic ouptut price (deviation from baseline)

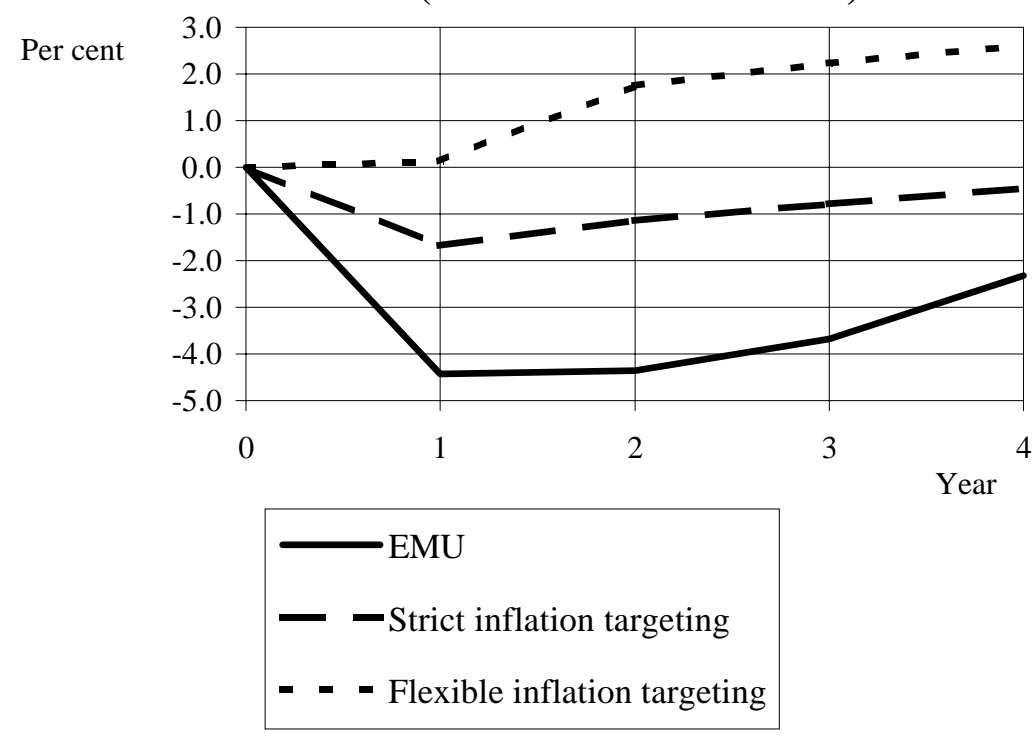

Figure 6. GDP

(deviation from baseline)

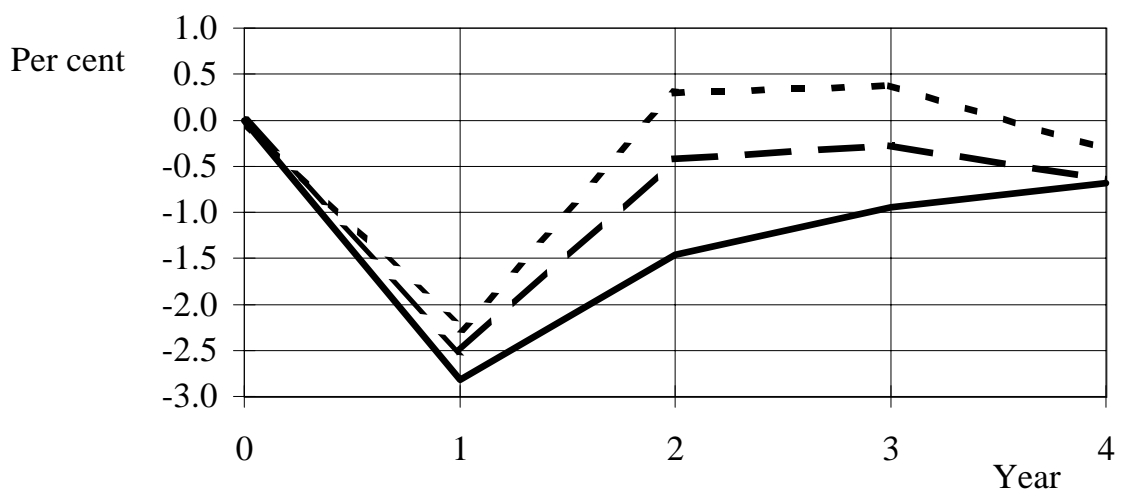


Figure 7. Increases in hourly earnings in manufacturing in Belgium, the Netherlands, and Germany.

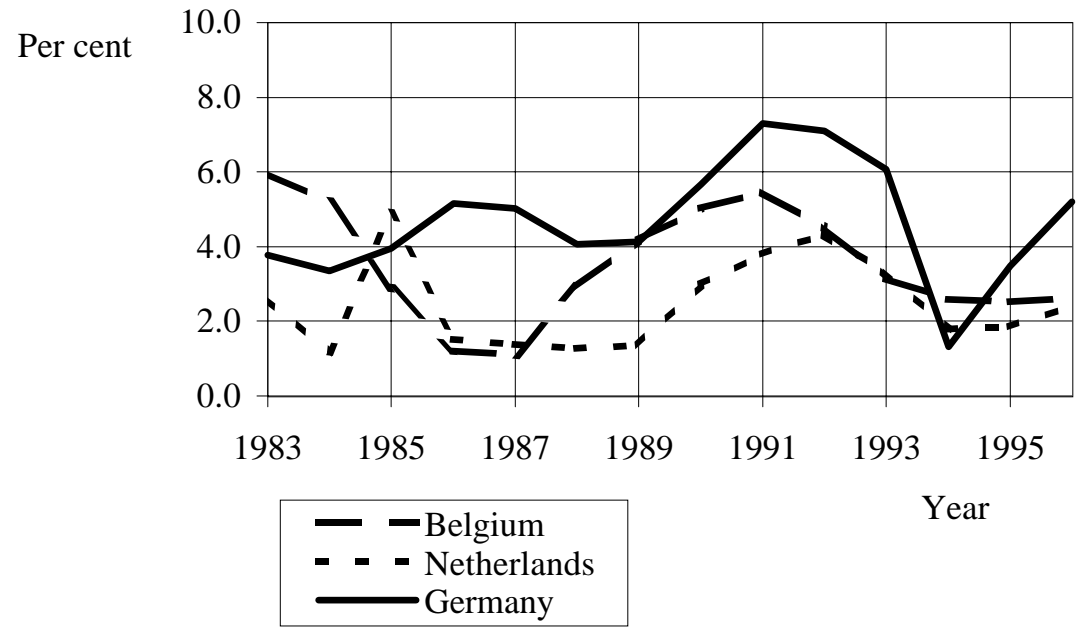

Source : OECD
Figure 8. Increases in hourly earnings in manufacturing in France, Austria, and Germany.

Per cent

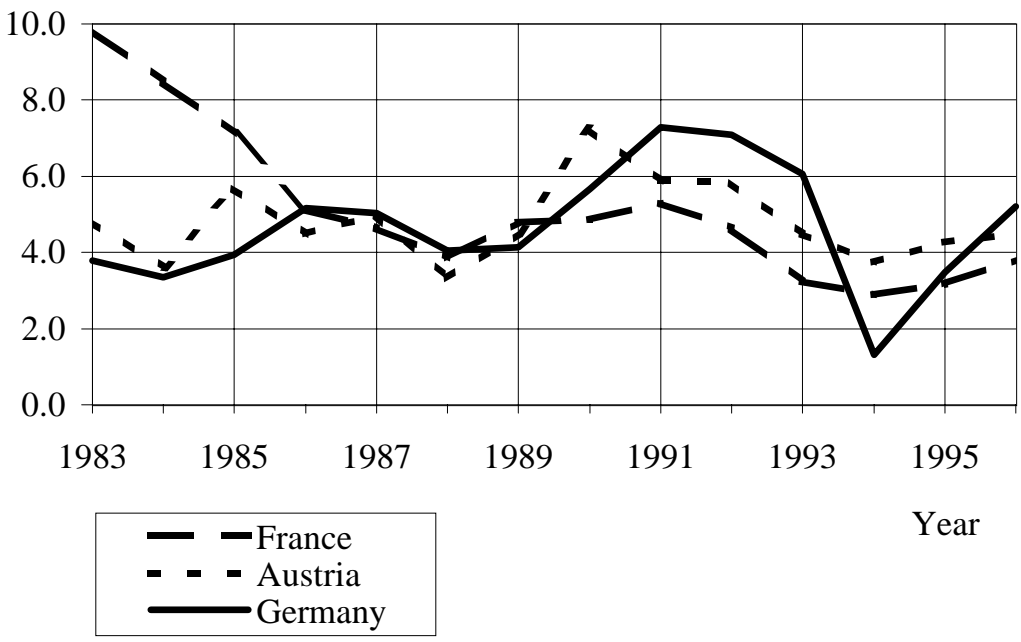

Source: OECD 
Figure 9. Labour-market reform and money-wage rigidity

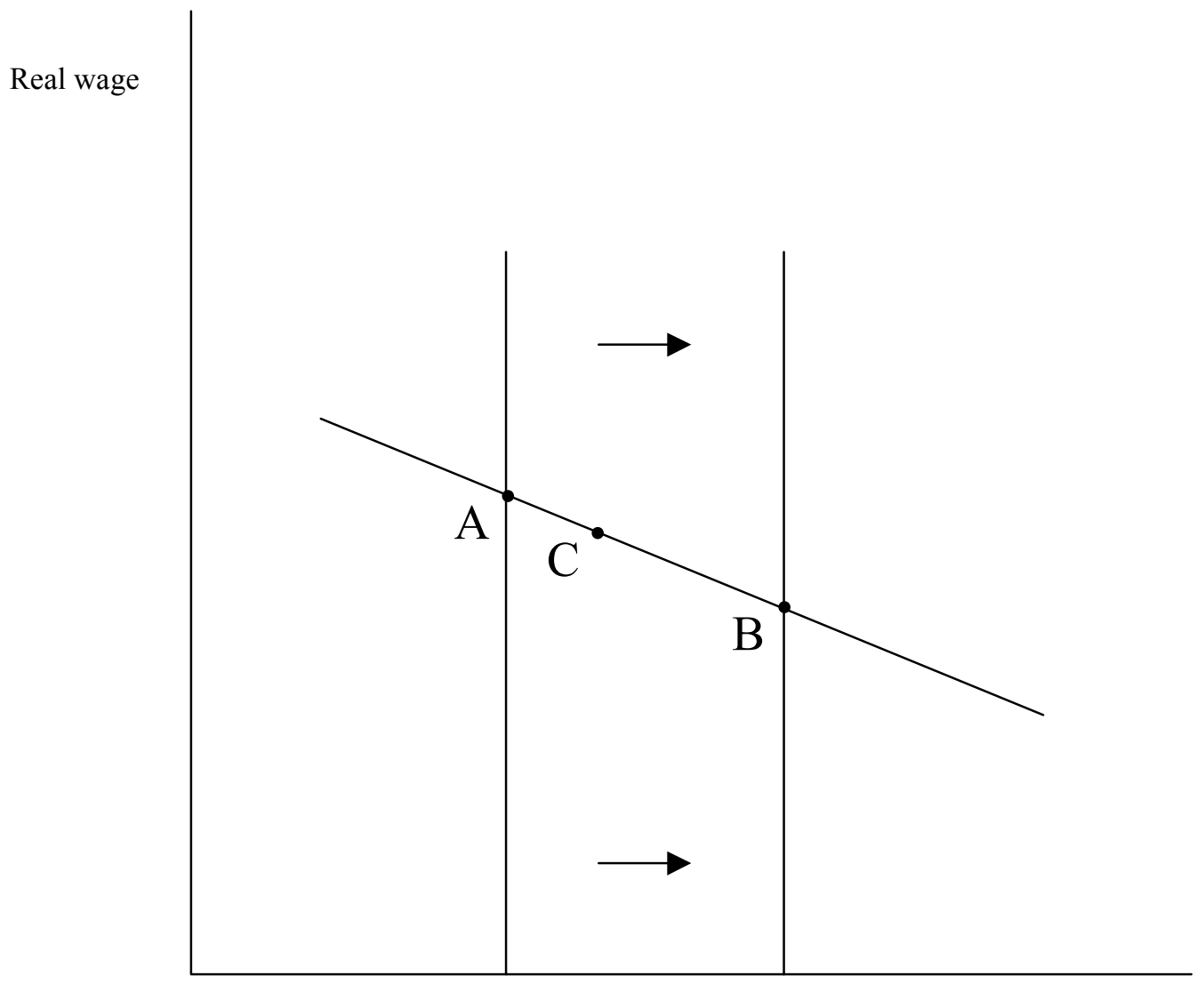

Employment 
Figure 10. The marginal disutility of unemployment

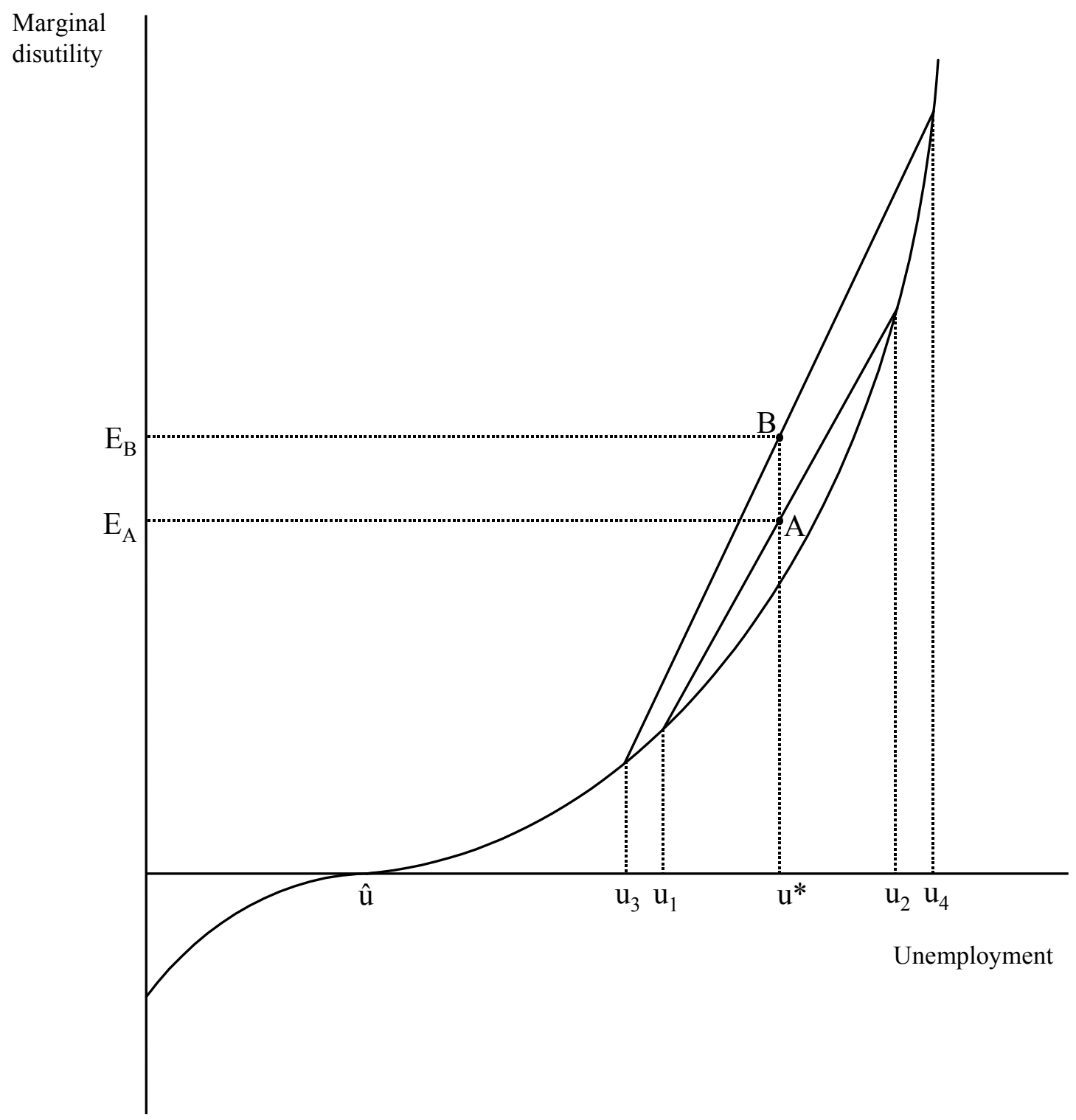

